\title{
Physiological, Morphological, and Histochemical Characterization of Three Classes of Interneurons in Rat Neostriatum
}

\author{
Yasuo Kawaguchi \\ Laboratory for Neural Systems, Frontier Research Program, RIKEN, Wako, 351-01 Japan and Laboratory for Neural \\ Circuits, Bio-mimetic Control Research Center, RIKEN, Atsuta-ku, Nagoya, 456 Japan
}

Interneurons in lateral part of neostriatum were studied in isolated slices from juvenile rats (16-20 d postnatal) by wholecell, current-clamp recording at $33-34^{\circ} \mathrm{C}$, followed by intracellular staining with biocytin and double immunocytochemical or histochemical staining for parvalbumin, ChAT, and NADPH diaphorase. Medium-sized spiny neurons (MS cells) had distal dendrites with many spines and were likely projection cells, while interneurons had dendrites with fewer spines. The neostriatal interneurons could be further divided into three classes by physiological, chemical, and morphological criteria.

The first class of interneurons (fast-spiking cells, FS cells) fired very short-duration action potentials with short-duration afterhyperpolarizations at constant spike frequency during depolarizing current pulses. FS cells had more negative resting potentials and lower input resistances than the other two classes. At depolarized potentials, FS cells fired repetitive spikes in response to synaptic excitation. FS cells were immunoreactive for parvalbumin. As all parvalbumin-immunoreactive cells in the neostriatum were also immunoreactive for GABA, FS cells were considered to be GABAergic. FS cells were further divided into two morphological types: FS cells with local dendritic fields and FS cells with extended dendritic fields. The axons of both types of FS cells had their densest collateralization within or near their dendritic fields.

The other two classes of interneuron, PLTS cells (persistent and low-threshold spike cells) and LA cells (long-lasting afterhyperpolarization cells), were distinguished from FS cells by longer-duration action potentials and larger input resistances, had less negative resting potentials, and had longerlasting afterhyperpolarizations. Afterhyperpolarizations of PLTS cells had a shorter time to peak than those of LA cells. PLTS cells fired both $\mathrm{Na}^{+}$-dependent, persistent depolarization spikes and $\mathrm{Ca}^{2+}$-dependent, low-threshold spikes in addition to fast spikes. Low-threshold spikes in PLTS cells were induced only from hyperpolarized potentials. Both persistent depolarizations and low-threshold spikes could also be evoked by synaptic activation. PLTS cells were histochemically identified as NADPH diaphorase-positive cells. As all NADPH diaphorase-positive cells in the same tissue

Received Feb. 24, 1993; revised May 17, 1993; accepted May 27, 1993.

This work was supported by a grant from the Human Frontier Science Program "The biology of information processing in the neostriatum" and the Frontier Research Program, RIKEN. I thank Prof. E. G. Jones for support and advice during the course of this study. I also thank Dr. Y. Kubota for helpful discussion, Dr. A. Agmon for comments on the manuscript, and Drs. R. Hattori and Y. Yui for supplying antiserum against NO synthase.

Correspondence should be addressed to Yasuo Kawaguchi at the above address.

Copyright (c) 1993 Society for Neuroscience $0270-6474 / 93 / 134908-16 \$ 05.00 / 0$ were immunoreactive for nitric oxide (NO) synthase, PLTS cells were considered to release NO. PLTS cells had the largest axonal fields. Some PLTS cells appeared to have two axonal origins from the somata and dendrites.

LA cells were mostly large aspiny cells with $\mathrm{Ca}^{2+}$-dependent long-lasting afterhyperpolarizations and strong timedependent hyperpolarizing rectification. As this slowly occurring anomalous rectification was blocked by $2 \mathrm{~mm}$ cesium, this potential was considered to be due to activation of $I_{h}$. LA cells were ChAT immunoreactive, and thus considered to be cholinergic. All LA cells were larger than $20 \mu \mathrm{m}$ in diameter. LA cells had more branched dendrites than PLTS cells.

Parvalbumin-, NO synthase, and ChAT-immunoreactive cells were not immunoreactive for either of the other two antigens. These findings show that neostriatal interneurons can be differentiated into at least three classes by differences in firing modes, territories of dendrites and axons, and content of neuroactive substances.

[Key words: interneuron, fast-spiking cell, low-threshold spike, parvalbumin, GABA, NADPH diaphorase, nitric oxide, ChAT, neostriatum, basal ganglia]

For functional understanding of any neuronal local circuit, it is necessary to reveal the physiological and morphological characteristics of its constituent neurons. These include membrane and synaptic potential properties, contained neurotransmitters, and dendritic and axonal arborization patterns. Within the mammalian neostriatum, the local circuitry is gradually becoming unravelled. Principal projecting cells are medium-sized cells (10-20 $\mu \mathrm{m}$ diameter) with spiny dendrites (MS cells) and have been well investigated from the above points of view (Gerfen, 1988; Wilson, 1990). Neostriatal neurons with fewer dendritic spines are considered to be interneurons. Compared to MS cells, neostriatal interneurons have not been well characterized physiologically. In particular, the physiological characteristics of neostriatal interneurons have not yet fully related to their morphological and chemical identities. Recent in vivo (Wilson et al., 1990) and in vitro (Kawaguchi, 1992) studies have shown that, compared with MS cells, large aspiny cells have different electrical properties and different dendritic and axonal arborization patterns. These studies suggest that other neostriatal interneurons may also show distinct physiological characteristics that may correlate with the morphological diversity of aspiny neuron types revealed in Golgi studies of the neostriatum.

Although morphological classifications of neostriatal cells are not completely consistent among several studies using Golgi staining (DiFiglia et al., 1976; Dimova et al., 1980; Chang et al., 1982; Bolam et al., 1984a), cumulative immunohistochem- 
ical evidence suggests that ncostriatal interneurons are mainly composed of three chemically identified populations. One population of neostriatal interneurons contains the calcium-binding protein parvalbumin (Cowan et al., 1990; Kita et al., 1990). Most of these are also strongly immunoreactive for both GABA and glutamate decarboxylase (GAD), the synthetic enzyme for GABA. Another population of interneurons is stained for NADPH diaphorase, an enzyme that is identical with nitric oxide (NO) synthase (Dawson et al., 1991). These cells also colocalize somatostatin and neuropeptide $\mathrm{Y}$ (Vincent et al., 1983; Dawson et al., 1991). Third population of interneurons is immunostained for ChAT, the rate-limiting enzyme in the synthesis of ACh (Bolam et al., 1984b; Phelps et al., 1985). These three populations are probably separate from one another (Kita et al., 1990; Dawson et al., 1991).

The present study investigated physiological properties of neostriatal cells in a slice preparation using whole-cell currentclamp recording combined with intracellular staining and immunocytochemistry or histochemistry to clarify the following three points important for understanding the functional differentiation of neostriatal local circuit neurons. First, is there a physiological heterogeneity among neostriatal interneurons and what properties are characteristic of each class of cells? Second, are there correlations between physiological subtypes and the three chemically defined classes? Third, are there morphological differences among physiologically and chemically different groups? The results show that physiological heterogeneity among the neostriatal interneurons correlates with specific chemical and morphological characteristics, implying that neostriatal neurons fall into three classes that differ in firing modes, neurochemical identity, and spatial territory subtended.

\section{Materials and Methods}

In vitro slice preparation and solutions used. The slicing and recording procedures used have been described in detail previously (Kawaguchi, 1992). The experiments were performed on young Wistar rats (16-20 d postnatal). The animals were deeply anesthetized with ether and decapitated. The brains were quickly removed, submerged in ice-cold physiological Ringer's and hemisected. Sections of the neostriatum were cut $180-200 \mu \mathrm{m}$ thick on a Microslicer (Dosaka EM) in a plane oblique to the horizontal along the line of rhinal fissure. After sectioning, neocortex was trimmed off. Slices were then incubated in oxygenated Ringer's solution at $29-30^{\circ} \mathrm{C}$. The standard Ringer's solution was composed of (mM) $\mathrm{NaCl}, 124.0 ; \mathrm{KCl}, 3.0 ; \mathrm{CaCl}_{2}, 2.4 ; \mathrm{MgCl}_{2}, 1.3 ; \mathrm{NaHCO}_{3}, 26.0$; $\mathrm{NaH}_{2} \mathrm{PO}_{4}, 1.0$; glucose, 10.0 ; and was continuously bubbled with a mixture of $95 \% \mathrm{O}_{2}$ and $5 \% \mathrm{CO}_{2}$. When replacing $\mathrm{CaCl}_{2}$ by $\mathrm{CoCl}_{2} \mathrm{NaH}_{2} \mathrm{PO}_{4}$ was omitted. Aftcr incubation for at least $2 \mathrm{hr}$, a single slice was transferred to a recording chamber placed on the stage of an upright microscope and was totally submerged in the superfusing medium at $33-34^{\circ} \mathrm{C}$. The remaining slices were kept in the holding chamber containing oxygenated Ringer's solution at $26-27^{\circ} \mathrm{C}$. All drugs were bath applied. Tetrodotoxin (TTX) came from Sankyo Co.

Whole-cell recording and stimulation. Individual neostriatal cells in lateral part were visualized using a $40 \times$ water immersion objective. Neostriatal cells that appeared larger than most other cells were preferentially targeted to obtain a larger sample of types of cells other than MS cells. Electrodes (borosilicate glass pipettes) were filled with a solution containing (mM) K-methylsulfate, 120; EGTA, $0.6 ; \mathrm{MgCl}_{2}, 2.0$; ATP, 4.0; GTP, 0.3; and HEPES, 10. The resistance of the electrodes filled with this solution was 5-6 M $\Omega$. Whole-cell recordings with a high scal rcsistance (more than $2 \mathrm{G} \Omega$ before break-in) were obtained using an amplifier with bridge balance and capacitance compensation. Input resistances were measured from the voltage deflection $(-6$ to $-15 \mathrm{mV})$ induced by hyperpolarizing current pulses. Time to peak and amplitude of afterhyperpolarizations following spikes werre measured from spike onset by depolarizing current pulses (duration, $0.5-1.0 \mathrm{sec}$ ) of threshold strength for spike initiation. Spike widths were measured at half-amplitude, on action potentials induced by depolarizing pulses (duration,
$50 \mathrm{msec}$ ) of threshold strength for spike initiation. Only one cell was recorded in each slice to facilitate comparison of physiological, immunohistochemical and morphological properties of single cells.

To identify the morphology of recorded cells, $0.5 \%$ biocytin (Sigma) was added to the pipette solution to stain cells by diffusion (Horikawa and Armstrong, 1988). Synaptic responses were evoked by electrical stimulation by bipolar electrodes at the white matter underlying neocortex (external capsule) or at sites more than $0.6-0.7 \mathrm{~mm}$ distant from the recorded neurons toward the external capsule. Stimuli of $100 \mu \mathrm{sec}$ duration and $0.2-0.5 \mathrm{~mA}$ intensity were delivered at $0.2-0.4 \mathrm{~Hz}$.

Immunohistochemical procedure for immersion-fixed slices. Slices containing biocytin-loaded cells were fixed by immersion in $4 \%$ paraformaldehyde and $0.2 \%$ picric acid in $0.1 \mathrm{~m}$ phosphate buffer $(\mathrm{PB})$ for $30-60 \mathrm{~min}$ at room temperature and incubated in PB containing $0.5 \%$ Triton $x-100$ (TX) for $1 \mathrm{hr}$. The tissue was frozen with dry ice and thawed in PB containing $0.5 \% \mathrm{TX}$ at room temperature. The slices, without resectioning, were then washed with Tris-buffered saline (TBS) for $1 \mathrm{hr}$. Each slice was further treated by one of the following four procedures.

(1) The slices were incubated with a mouse monoclonal antibody against parvalbumin (Sigma; diluted 1:2000) in TBS containing 10\% normal goat serum (NGS), $2 \%$ bovine serum albumin (BSA), and $0.5 \%$ TX, overnight at room temperature. After $3 \times 10$ min washing in TBS, the slices were incubated in a mixture containing the streptavidin-conjugated Texas red (Amersham; diluted 1:200) and dichlorotriazinylaminofluorescence-dihydrochloride (DTAF)-conjugated goat anti-mouse IgG (Chemicon; 1:200) in TBS containing 10\% NGS, 2\% BSA for $3 \mathrm{hr}$ at room temperature.

(2) The slices were incubated with the streptavidin-conjugated Texas red $(1: 200)$ in TBS containing $10 \%$ NGS, $2 \%$ BSA for $3 \mathrm{hr}$ at room temperature. After $3 \times 10 \mathrm{~min}$ washing in TBS, the slices were processed for NADPH diaphorase histochemistry by incubating in a solution containing $1 \mathrm{mg} / \mathrm{ml} \mathrm{NADPH}$ and $0.2 \mathrm{mg} / \mathrm{ml}$ nitroblue tetrazolium in 0.1 M Tris buffer (TB) at $37^{\circ} \mathrm{C}$ for $20-30 \mathrm{~min}$.

(3) The slices were incubated with a rat monoclonal antibody against choline acetyltransferase (Boehringer; $1 \mu \mathrm{g} / \mathrm{ml}$ ) in TBS containing $10 \%$ NGS, $2 \%$ BSA and $0.5 \%$ TX, overnight at room temperature. After $3 \times 10 \mathrm{~min}$ washing in TBS, the slices were incubated in a mixture containing the streptavidin-conjugated Texas red $(1: 200)$ and FITCconjugated goat anti-rat IgG (Jackson; 1:200) in TBS containing 10\% NGS, $2 \%$ BSA for $3 \mathrm{hr}$ at room temperature.

(4) In some slices, no histochemical procedures were applied.

In the cases treated with histochemical procedures $1-3$, after $3 \times 10$ min washing in TBS, the slices were observed and photographed in a fluorescence microscope (Nikon Microphot-FXA) using epifluorescence the $\mathrm{G}-2 \mathrm{~A}$ (barrier filter $>590 \mathrm{~nm}$ ) dichroic mirror system for Texas red to identify biocytin-labeled cells, epifluorescence B-2E (barrier filter, $520-560 \mathrm{~nm}$ ) for DTAF and FITC to examine immunoreactive cells, or bright-field optics for NADPH diaphorase-positive cells. The immunoreactive cells were seen in red or green fluorescence with the respective filter systems, and only one color was visualized by each filter combination in epifluorescence.

In all cases, slices were next incubated to make staining for biocytin more permanent. They were incubated in TBS containing $0.5 \% \mathrm{H}_{2} \mathrm{O}_{2}$ for $30 \mathrm{~min}$ to suppress endogenous peroxidase activity. After washing in TBS for $3 \times 20 \mathrm{~min}$, the slices were incubated with avidin-biotinperoxidase complex (Vector; $1: 100$ ) in TBS for $3 \mathrm{hr}$ at room temperature. After washing in TBS for $20 \mathrm{~min}$, the slices were again incubated with avidin-peroxidase (Vector; 1:100) in TBS for $3 \mathrm{hr}$ at room temperature. After washing in $\mathrm{PB}$, the slices were reacted with $3,3^{\prime}$-diaminobenzidine tetrahydrochloride (DAB) $(0.05 \%)$ and $\mathrm{H}_{2} \mathrm{O}_{2}(0.003 \%)$ in $\mathrm{PB}$. The sections were postfixed in $0.1 \%$ osmium tetroxide in $\mathrm{PB}$ for $10 \mathrm{~min}$ and mounted on gelatin-coated glass slides. Mounted slices were dehydrated and embedded in Epon 812 (Fluka). The dendrites, axonal processes, and somata of the biocytin-labeled neurons were drawn at $600 \times$ using a $60 \times 1.4$ NA objective and a camera lucida. Data are given as means $\pm \mathrm{SD}$. For statistical analysis in comparing cell classes, the Mann-Whitney $U$ test was used.

Immunohistochemistry in perfusion-fixed brains. Four male Wistar rats (16 and $20 \mathrm{~d}$ postnatal) were used. The animals were given an overdose of Nembutal and perfused through the heart with phosphatebuffered saline, followed by $150 \mathrm{ml}$ of fixative containing $2 \%$ paraformaldehyde, $0.2 \%$ picric acid, and $0.1 \%$ glutaraldehyde in $\mathrm{PB}$. The brains were removed and postfixed in the same fixative for $3 \mathrm{hr}$ at $4^{\circ} \mathrm{C}$. After incubation in $\mathrm{PB}$ containing $30 \%$ sucrose for $3 \mathrm{~d}$ at $4^{\circ} \mathrm{C}$, the sections 
Table 1. Properties of four types of neostriatal cells

\begin{tabular}{|c|c|c|c|c|}
\hline & $\begin{array}{l}\text { MS cells } \\
(n=17)\end{array}$ & $\begin{array}{l}\text { FS cells } \\
(n=13)\end{array}$ & $\begin{array}{l}\text { PLTS cells } \\
(n=11)\end{array}$ & $\begin{array}{l}\text { LA cells } \\
(n=26)\end{array}$ \\
\hline Soma diameter $(\mu \mathrm{m})$ & $\begin{array}{c}13.0 \pm 2.1 \\
(<\mathrm{FS},<\mathrm{PLTS},<\mathrm{LA})\end{array}$ & $\begin{array}{r}17.4 \pm 3.5 \\
(>\mathrm{MS},<\mathrm{LA})\end{array}$ & $\begin{array}{r}18.7 \pm 3.2 \\
(>\mathrm{MS},<\mathrm{LA})\end{array}$ & $\begin{aligned} 26.7 & \pm 4.3 \\
(>\mathrm{MS}, & >\mathrm{FS},>\mathrm{PLTS})\end{aligned}$ \\
\hline Kesting potential (mV) & $\begin{array}{l}-81.1 \pm 4.4 \\
(<\text { PLTS, }<\text { LA })\end{array}$ & $\begin{array}{l}-79.9 \pm 3.2 \\
(<\text { PLTS, }<\text { LA })\end{array}$ & $\begin{array}{l}-56.4 \pm 15.7 \\
(>\mathrm{MS},>\mathrm{FS})\end{array}$ & $\begin{array}{l}-57.3 \pm 5.0 \\
(>\mathrm{MS},>\mathrm{FS})\end{array}$ \\
\hline Input resistance ${ }^{a}(\mathrm{M} \Omega)$ & $\begin{array}{c}193 \pm 77 \\
(>\mathrm{FS},<\mathrm{PLTS},<\mathrm{LA})\end{array}$ & $\begin{aligned} 86 & \pm 38 \\
(<\mathrm{MS}, & <\mathrm{PLTS},<\mathrm{LA})\end{aligned}$ & $\begin{aligned} 638 & \pm 245 \\
(>\mathrm{MS}, & >\mathrm{FS})\end{aligned}$ & $\begin{aligned} 433 & \pm 231 \\
(>\mathrm{MS}, & >\mathrm{FS})\end{aligned}$ \\
\hline Spike width at half amplitude (msec) & $\begin{aligned} & 1.05 \pm 0.20 \\
(>\mathrm{FS}) & \end{aligned}$ & $\begin{array}{c}0.29 \pm 0.04 \\
(<\mathrm{MS},<\text { PLTS },<\text { LA })\end{array}$ & $\begin{array}{r}1.00 \pm 0.41 \\
(>\mathrm{FS})\end{array}$ & $\begin{array}{r}0.82 \pm 0.19 \\
(>\mathrm{FS})\end{array}$ \\
\hline Time to peak of $\mathrm{AHP}^{t}(\mathrm{msec})$ & $\begin{array}{r}22.9 \pm 6.6 \\
(>\mathrm{FS},<\mathrm{LA})\end{array}$ & $\begin{aligned} 1.3 & \pm 0.27 \\
(<\mathrm{MS}, & <\mathrm{PLTS},<\mathrm{LA})\end{aligned}$ & $\begin{array}{r}13.6 \pm 8.2 \\
(>\mathrm{FS},<\mathrm{LA})\end{array}$ & $\begin{array}{c}53.2 \pm 17.1 \\
(>\mathrm{MS},>\mathrm{FS},>\mathrm{LA})\end{array}$ \\
\hline Amplitude of $\mathrm{AHP}^{b}(\mathrm{mV})$ & $\begin{array}{l}-13.7 \pm 2.4 \\
(>\mathrm{FS},>\mathrm{LA})\end{array}$ & $\begin{array}{l}-23.3 \pm 3.8 \\
(<\mathrm{MS})\end{array}$ & $-19.9 \pm 6.5$ & $\begin{array}{l}-21.6 \pm 5.4 \\
(<\mathrm{MS})\end{array}$ \\
\hline
\end{tabular}

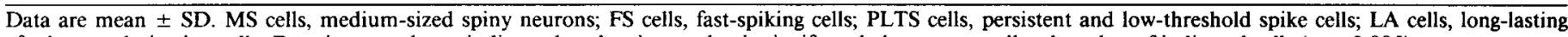
afterhyperpolarization cells. Data in parentheses indicate that the given value is significantly larger or smaller than that of indicated cells ( $p \leq 0.005)$.

"Input resistance and time constant were determined by hyperpolarizing current pulses inducing voltage shift of $6-15 \mathrm{mV}$ negative to rest.

"Time to peak and amplitude of afterhyperpolarization (AHP) were measured from the spike onset.

were cut along the line of the rhinal fissure in a cryostat at $10 \mu \mathrm{m}$ thickness and mounted on gelatin-coated slides. The sections were washed several times in TBS and were further treated by one of the following three procedures.

(1) In preparations to be triple stained for parvalbumin, NO synthase, and choline acetyltransferase, the sections were incubated with the same monoclonal mouse antibody against parvalbumin as above (diluted 1:2000), with a rabbit antiserum against NO synthase that had been purified from rat cerebellum and was an enzyme of constitutive type (from Drs. Hattori and Yui, Kyoto University; diluted 1:2000) and with the rat monoclonal antibody against choline acetyltransferase $(1 \mu \mathrm{g} /$ $\mathrm{ml}$ ) in TBS containing $10 \% \mathrm{NGS}, 2 \% \mathrm{BSA}$, and $0.5 \% \mathrm{TX}$ for overnight at room temperature. After $3 \times 10 \mathrm{~min}$ washing in TBS, the sections were incubated with TRITC-conjugated goat anti-mouse IgG (Chemicon; 1:200), biotinylated goat anti-rabbit IgG (Vector; 1:200) and DTAFconjugated goat anti-rat IgG (Chemicon; $1: 200$ ) in TBS containing $10 \%$ NGS, $2 \%$ BSA for $3 \mathrm{hr}$ at room temperature. After $3 \times 10$ min washing in TBS, the sections were incubated with AMCA-streptavidin (Vector; 1:100) in TBS for $3 \mathrm{hr}$ at room temperature.

(2) In preparations to be double stained for NADPH diaphorase and NO synthase, the sections were incubated with the rabbit serum against NO synthase in TBS containing $10 \%$ NGS, $2 \%$ BSA, and $0.5 \%$ TX for overnight at room temperature. After $3 \times 10$ min washing in TBS, the scctions wcrc incubated with biotinylated goat anti-rabbit IgG (1:200) in TBS containing $10 \%$ NGS, $2 \%$ BSA for $3 \mathrm{hr}$ at room temperature. After $3 \times 10 \mathrm{~min}$ washing in TBS, they were incubated with streptavidin Texas red $(1: 200)$ for $3 \mathrm{hr}$ at room temperature. After $3 \times 10 \mathrm{~min}$ washing in TBS, they were washed with TB and were processed for NADPH diaphorase histochemistry by incubation in a solution containing $1 \mathrm{mg} / \mathrm{ml} \mathrm{NADPH}$ and $0.2 \mathrm{mg} / \mathrm{ml}$ nitroblue tetrazolium in TB at $37^{\circ} \mathrm{C}$ for $20-30 \mathrm{~min}$.

(3) In preparations to be double stained for parvalbumin and GABA, the sections were incubated with the monoclonal mouse antibody against parvalbumin (diluted 1:2000) and a rabbit antiserum against GABA (Sigma; diluted 1:4000) in TBS containing 10\% NGS, 2\% BSA, and $0.5 \% \mathrm{TX}$ overnight at room temperature. After $3 \times 10 \mathrm{~min}$ washing in TBS, the sections were incubated in DTAF-conjugated goat anti-mouse $\operatorname{IgG}(1: 200)$ and TRITC-conjugated donkey anti-rabbit IgG (Chemicon; $1: 200$ ) in TBS containing $10 \%$ NGS, $2 \%$ BSA for $3 \mathrm{hr}$ at room temperature.
After each of the above three procedures, the sections were washed in TBS several times and mounted on slides with $50 \%$ glycerin in TBS. The sections were observed and photographed in a fluorescence microscope (Nikon Microphot-FXA) using the G-2A (barrier filter $>590 \mathrm{~nm}$ ) dichroic mirror system for TRITC and Texas red, B-2E (barrier filter, 520-560 nm) for DTAF, UV-2A (barrier filter > $420 \mathrm{~nm}$ ) for AMCA, or bright-field optics for NADPH diaphorase-positive cells. In addition, a band-pass filter (400-500 nm; BPB-45 FUJI) was used for AMCA. The cells were seen in red, green, or blue fluorescence with the respective filter systems, and only one color was visualized by each filter combination.

Cross-reactivity of the secondary antibodies. Selected sections were incubated with a single primary antibody and then incubated with the secondary antibody appropriate to the other primary; for example, one set of sections was incubated in mouse monoclonal antibody against parvalbumin and then in TRITC-conjugated goat anti-rabbit IgG. In none of the possible combinations was specific staining observed.

\section{Results}

All neurons sampled by whole-cell recording from the lateral part of the neostriatum had resting potentials more negative than $-40 \mathrm{mV}$ and overshooting spikes. All electrophysiological data used for the analysis came from 17 MS cells and 50 cells of other types, which were all morphologically identified and satisfied the above electrophysiological criteria (Table 1). Staining intracellularly with biocytin clearly distinguished the morphologies of MS cells and other classes of cells. In no cases were two or more cells stained by a single whole-cell recording. Diameter of MS cells ranged from 9 to $17 \mu \mathrm{m}$. MS cells had distal dendrites with many spines (Fig. 1 $1, B$ ). The axons of MS cells emitted local collaterals that remained close to the dendritic field. Main axons of MS cells sometimes could be traced into fiber bundles in the neostriatum. Other types of cells had dendrites either lacking spines or with fewer spines than MS cells;

Figure 1. Photomicrographs of four classes of rat neostriatal cells intracellularly stained by biocytin. $B, D, F$, and $H$ are higher magnifications of $A, C, E$, and $G$, respectively. $A$ and $B$, An MS (medium spiny) cell. Note the dendrites with many spines. $C$ and $D$, An FS (fast-spiking) cell. $E$ and $F$, A PLTS (persistent and low-threshold spike) cell. Note the dendrites with fewer spines in FS and PITS cell than MS cell. $G$ and $H$, An LA (longer-duration afterhyperpolarization) cell. Note a larger soma than other cells. Scale bars: $G, 100 \mu \mathrm{m}$ for $A, C, E$, and $G ; H, 50 \mu \mathrm{m}$ for $B, D, F$, and $H$. 

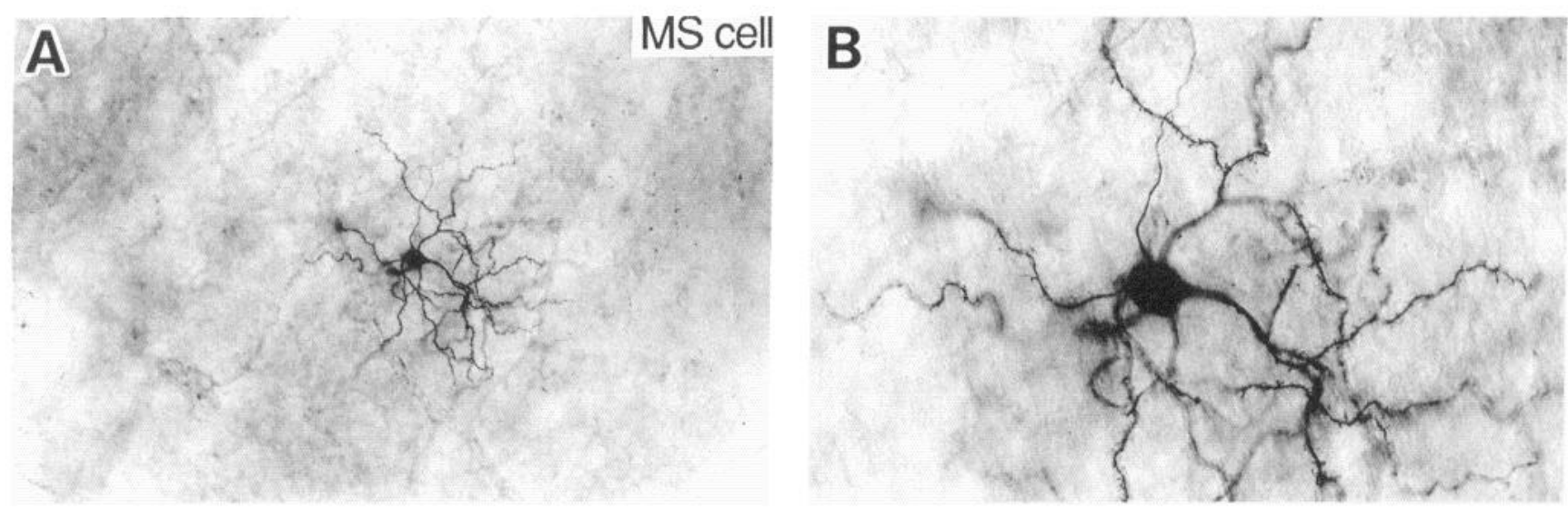

C

FS cell D

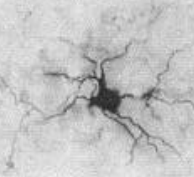

E

P LTS cell
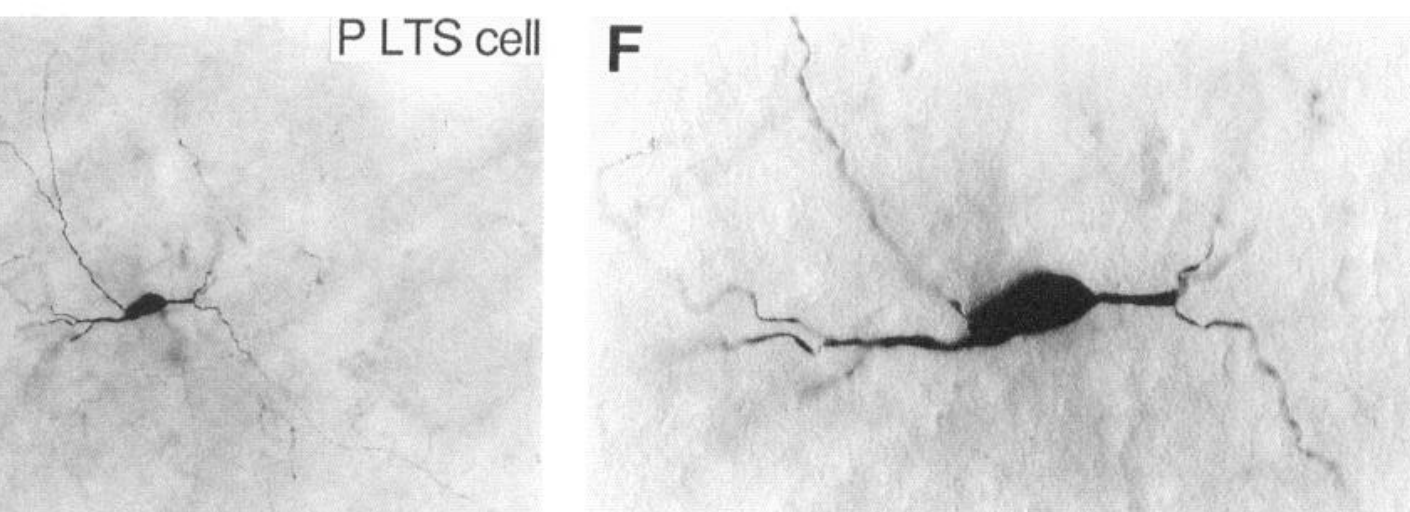

G

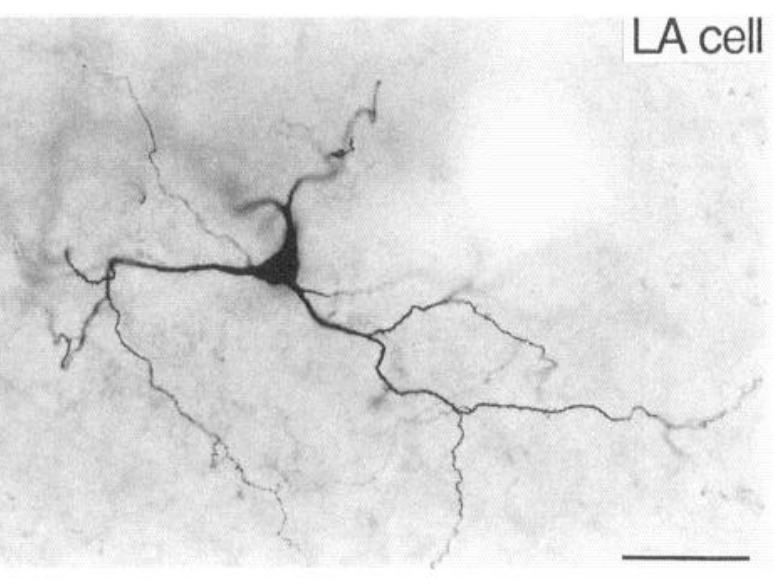

H

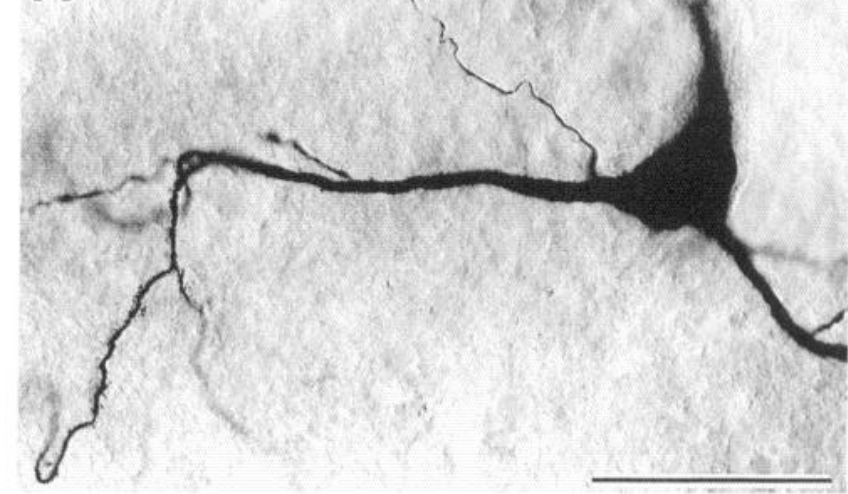




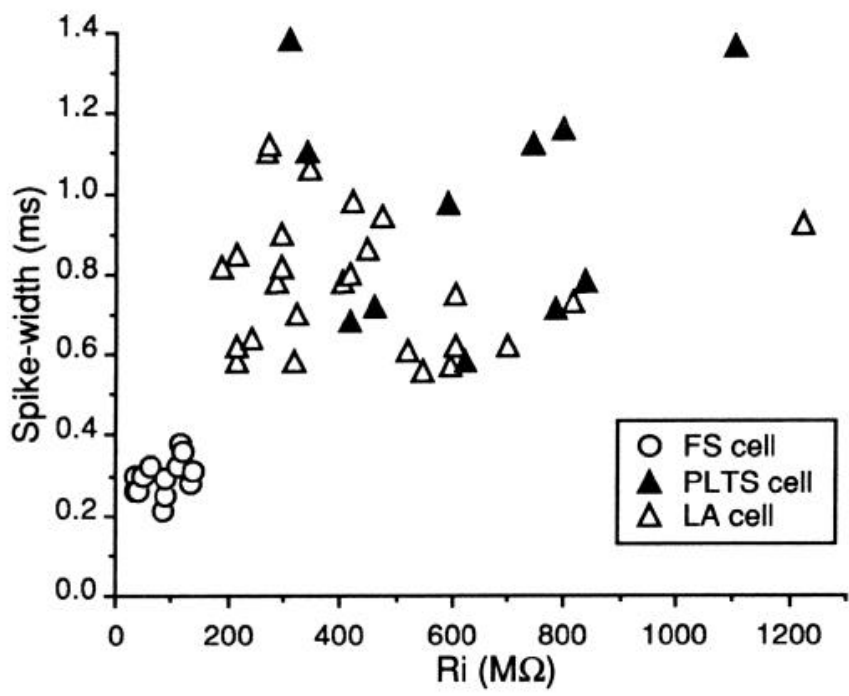

Figure 2. Plot of spike widths at half-amplitude (spike-width) versus input resistances $(R i)$ of three classes of interneurons in rat neostriatum, FS cell (open circles), PLTS cell (solid triangles), and LA cell (open triangles). FS cells had spike widths shorter than $0.4 \mathrm{msec}$ and input resistances lower than $140 \mathrm{M} \Omega$. PLTS and LA cells had spike widths longer than $0.5 \mathrm{msec}$ and input resistances higher than $180 \mathrm{M} \Omega$.

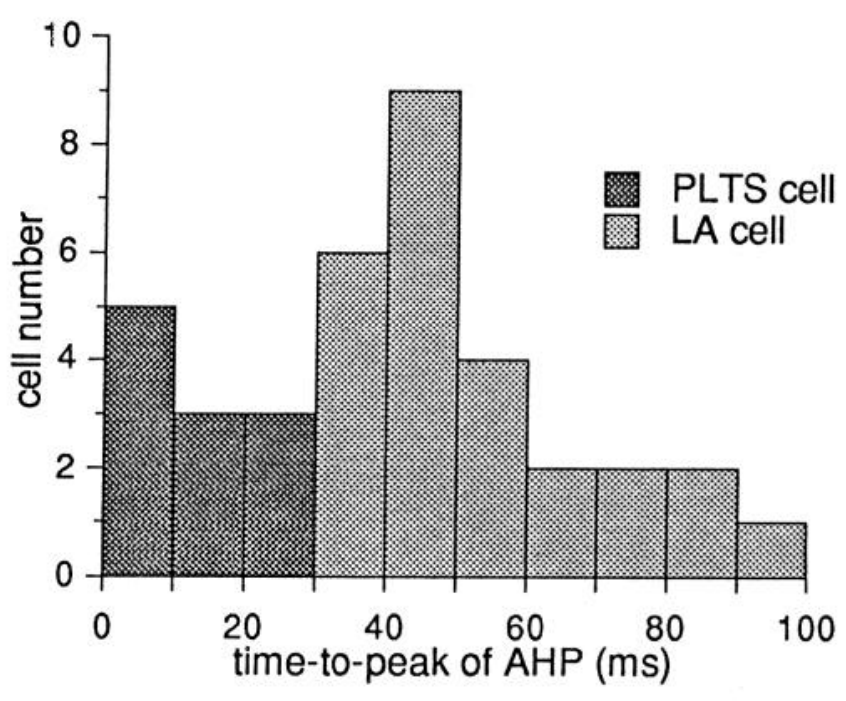

Figure 4. Distributions of time to peak of afterhyperpolarization $(A H P)$ following spikes of PLTS cells and LA cells. Time to peak of afterhyperpolarizations was measured from onsets of spikes that were elicited by threshold depolarizing current stimuli. Note times to peak of PLTS cells and LA cells are smaller and larger than $30 \mathrm{msec}$, respectively.
Figure 3. Physiological characteristics of an FS cell. $A 1$, A spike elicited by a depolarizing pulse. Note short-duration spike and short afterhyperpolarization following a spike. $A 2$, Voltage responses induced by current pulses and repetitive spike discharges induced by current pulse close to the threshold. Note the slowly depolarized phase before spike initiation (arrowhead), abrupt cessation of firing, and late resumed firing. Spikes are truncated due to sampling frequency. $A_{3}$, A stronger pulse induced early single firing and late repetitive firing. Note abrupt cessation of repetitive firing and weak adaptation of firing rate during repetitive discharges. $A_{1}-A_{3}$ are from the same FS cell and have the same calibration. Resting membrane potential, $-73 \mathrm{mV}$. $B$, The slowly depolarized phase in FS cells became clear by elimination of spike discharges by $1 \mu \mathrm{M}$ TTX (arrowhead). Spontaneous synaptic potentials could be observed. $C_{1}$, Repetitive firing by synaptic stimulation (arrowhead) of FS cell in combination with depolarization $(-38 \mathrm{mV})$ by depolarizing currents. $C_{2}$, Synaptic excitation of FS cell with a spike elicited by synaptic stimulation (arrowhead) at resting potential $(-73$ $\mathrm{mV}) . \mathrm{C}_{1}$ and $\mathrm{C}_{2}$ have the same calibration.
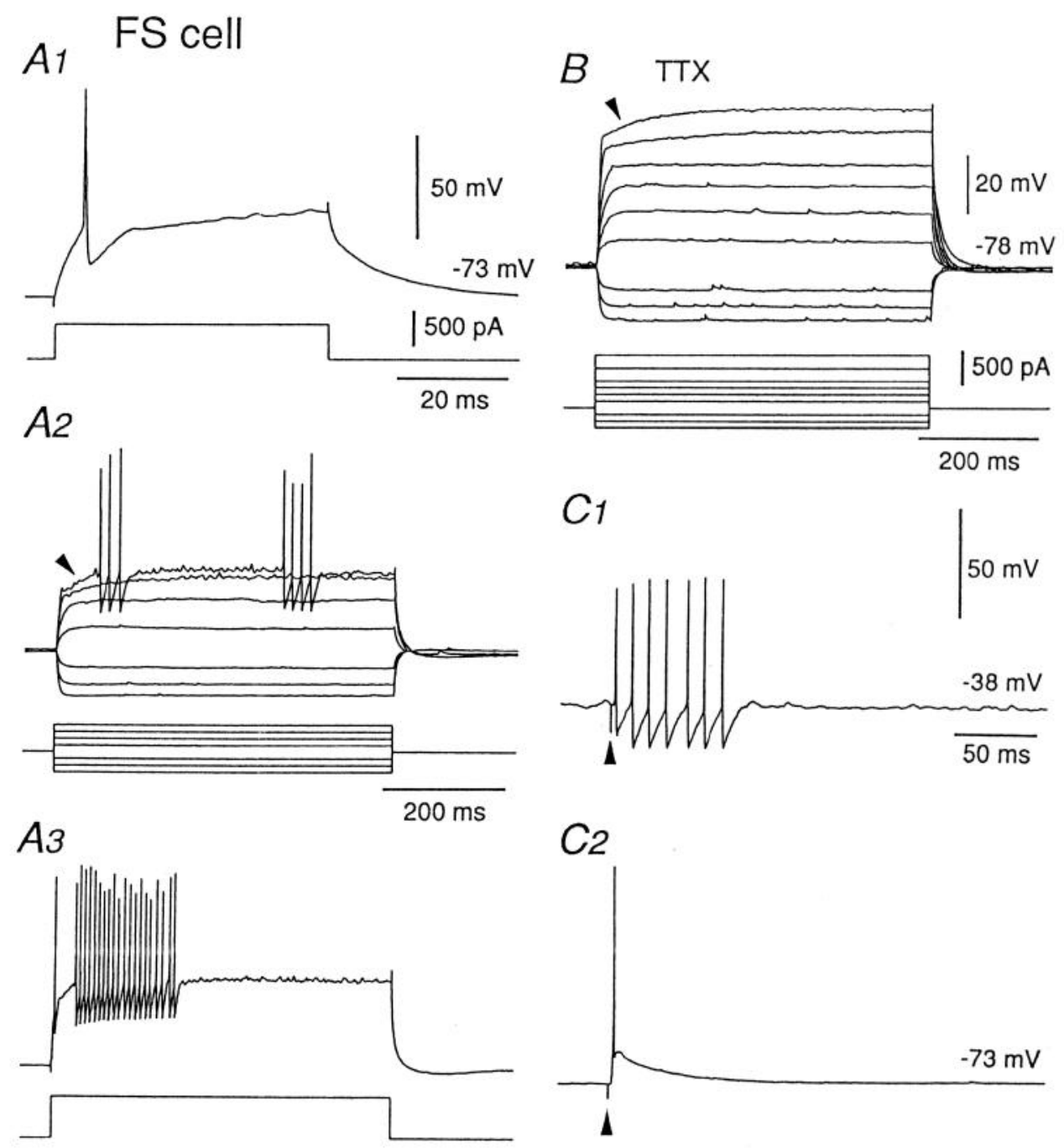


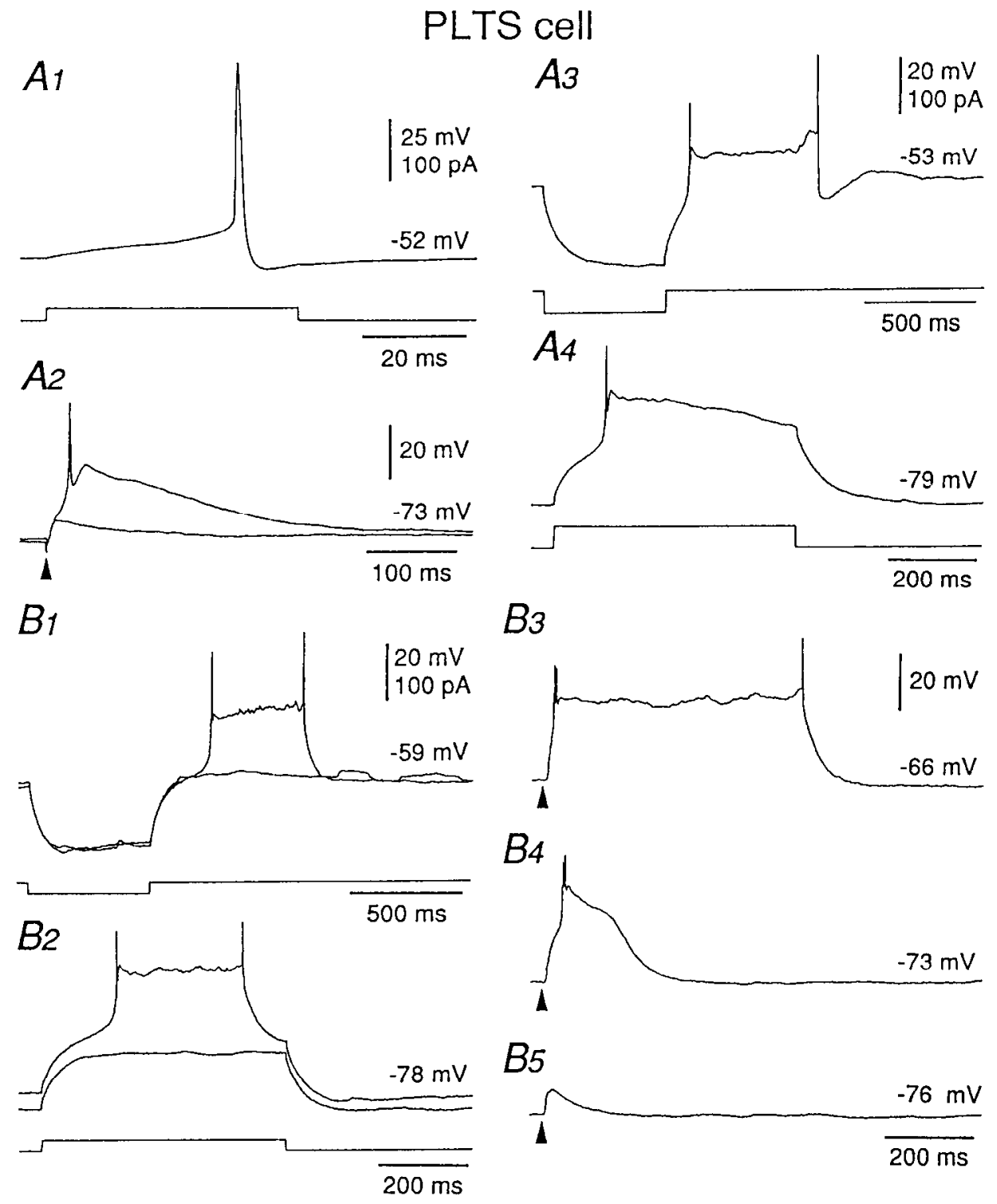

Figure 5. Physiological characteristics of PLTS cells. $A t$, A single spike was elicited by a depolarizing pulse. Note longer duration of spike compared to FS cells (Fig. $3 A I$ ). $A 2$, An allor-none low-threshold spike with a fast spike was induced by synaptic excitation (arrowhead) at hyperpolarized potential. $A \boldsymbol{A}, \mathrm{A}$ long-lasting persistent depolarization followed by low-threshold spikes was elicited by cessation of the hyperpolarizing pulse from depolarized potentials. This long-lasting persistent depolarization was terminated by the afterhyperpolarization following a fast spike. A4, Low-threshold spikes were also elicited by depolarizing pulses from hyperpolarized potentials. $B \boldsymbol{B}-\boldsymbol{B}$, , Persistent depolarizations following lowthreshold spikes could be induced by both a current step and synaptic excitation. $B I$ and $B 2$, Low-threshold spike and following persistent depolarization by cessation of hyperpolarizing pulses at depolarized potentials $(B I)$ and by depolarizing pulses at hyperpolarized potentials $(B 2)$ in all-or-none fashion. $B 3-B 5$, Persistent depolarizations could be also induced by sufficient synaptic excitation. At hyperpolarized potentials, no spikes were induced by synaptic excitation (arrowhead) (Bs). Only low-threshold spikes could be elicited synaptically at $-73 \mathrm{mV}(B 4)$, but at -66 $\mathrm{mV}$ persistent depolarizations could be also elicited following low-threshold spikes $(B 3)$. Membrane potentials are shown on each record. In slower sweeps, spikes are truncated.

their main axons did not run in the neostriatal fiber bundles (Fig. $1 C-H$ ) and they were considered interneurons.

The electrophysiological characteristics of MS cells were essentially the same as previously described (Kita et al., 1984; Kawaguchi et al., 1989; Calabresi et al., 1990; Jiang and North, 1991; Kawaguchi, 1992). Morphological types of cells other than MS cells that were considered to be interneurons could be further divided into three physiological classes. Interneurons of the first class fired very short-duration action potentials at constant spike frequency and are called fast-spiking cells (FS cells). Interneurons of the second class fired both $\mathrm{Na}^{+}$-dependent persistent depolarization spikes and $\mathrm{Ca}^{2+}$-dependent low-threshold spikes, and are called persistent and low-threshold spike cells (PLTS cells). The third class of interneurons were mostly large aspiny cells with long-lasting afterhyperpolarizations and strong timedependent hyperpolarizing rectification, and are called longlasting afterhyperpolarization cells (LA cells). They were also different in chemical and morphological characteristics. First, the electrophysiological properties of the three classes of interneurons will be described.
Physiological properties of three classes of neostriatal interneurons

Fast-spiking cells (FS cells). Among 50 identified neostriatal interneurons, 13 cells bclonged to the FS class. A readily distinguishable feature of FS cells was short-duration action potentials with afterhyperpolarizations that had shorter times to peak than other classes of cells (Table 1; Figs. 2, 3AI). Another characteristic feature was their lower input resistances compared with other classes of cells. FS cells had spike widths at halfamplitude shorter than $0.4 \mathrm{msec}$ and input resistances lower than $140 \mathrm{M} \Omega$, while PLTS cells and LA cells had spike widths at half-amplitude longer than $0.5 \mathrm{msec}$ and input resistances higher than $180 \mathrm{M} \Omega$ (Fig. 2). Resting membrane potentials of FS cells were more negative than those of PLTS cells and LA cells. In FS cells, depolarizing current pulses with strength just below threshold produced membrane depolarization having two distinct phases, an initial rapidly rising component followed by slow depolarization with a duration of about $100 \mathrm{msec}$ (Fig. $3 A 2$ ). Eliminating $\mathrm{Na}^{+}$-dependent fast spikes by TTX made this 


\section{PLTS cell}

A1
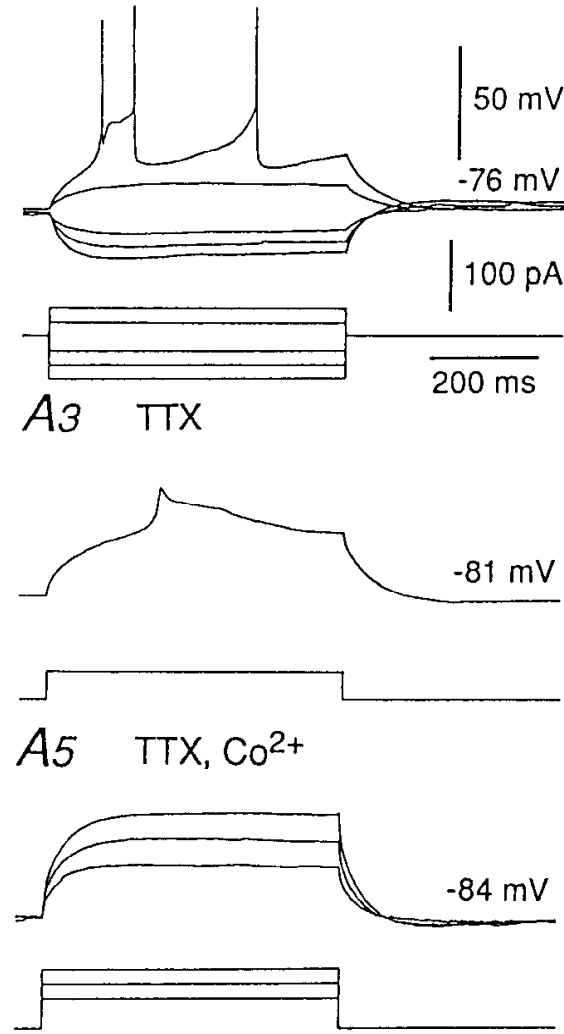

A2

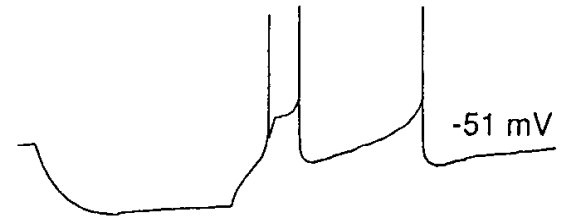

$B_{1}$
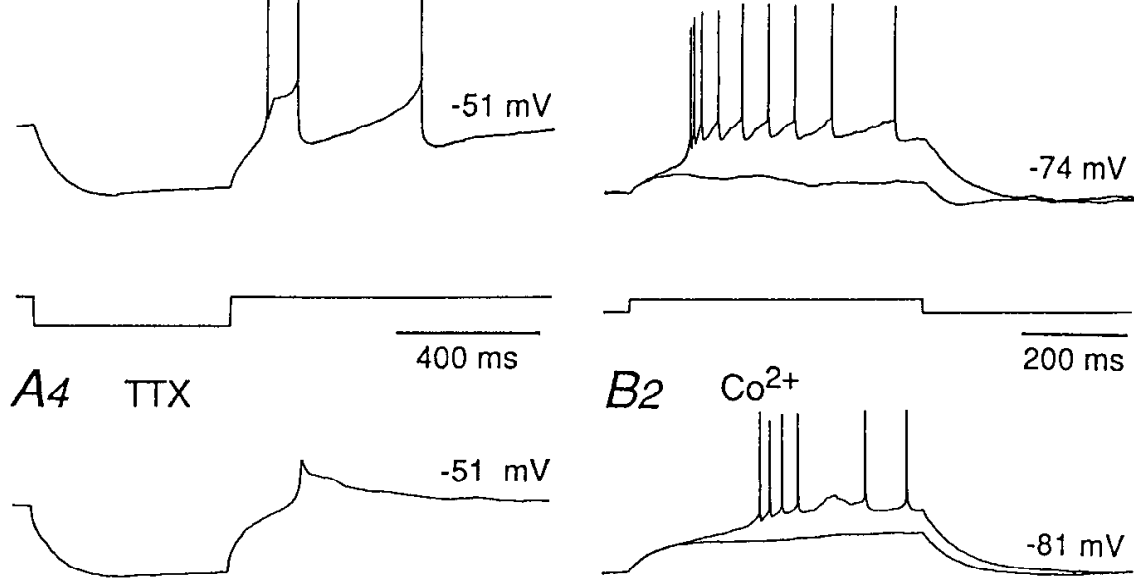

$200 \mathrm{~ms}$
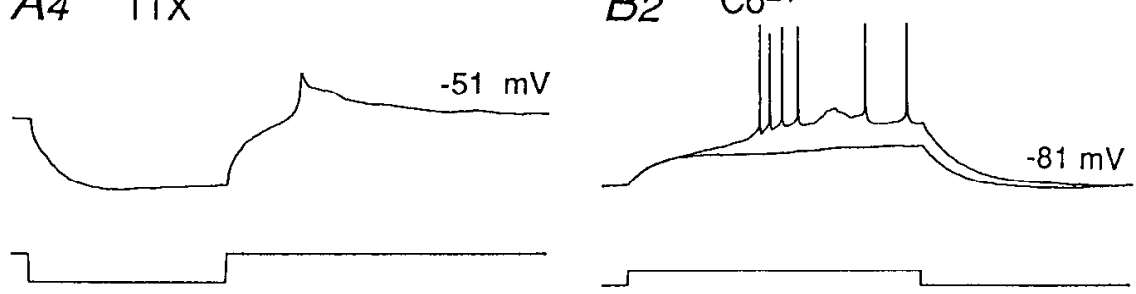

A6 TTX, $\mathrm{Co}^{2+}$

$-43 \mathrm{mV}$
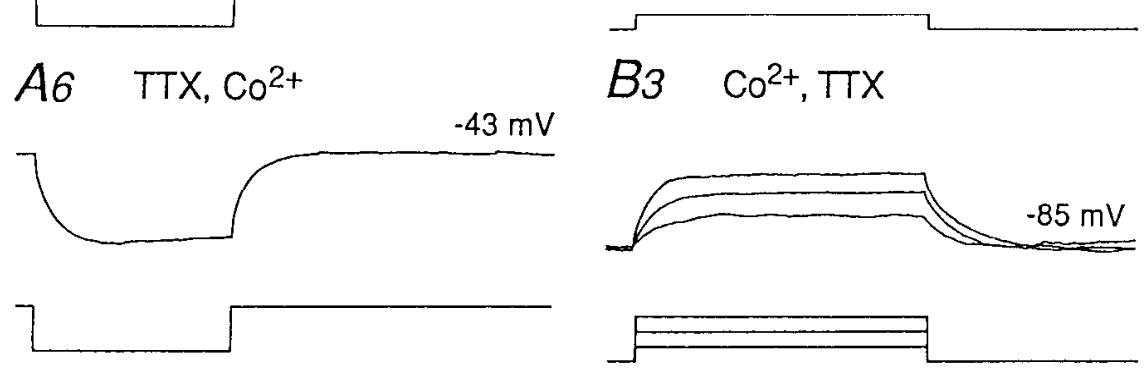

Figure 6. Properties of low-threshold spikes and persistent depolarizations in PLTS cells. $A l$ and $A 2$, Low-threshold spikes induced by depolarizing pulses $\left(A_{1}\right)$ and cessation of hyperpolarizing pulses $\left(A_{2}\right) . A_{3}$ and $\mathrm{A}_{4}$. Low-threshold spikes could not be abolished by $1 \mu \mathrm{M}$ TTX application. $A 5$ and A6, Low-threshold spikes were abolished by replacement of $\mathrm{Ca}^{2+}$ by $2 \mathrm{~mm} \mathrm{Co}^{2+}$. B1, All-or-none induction of low-threshold spike followed by persistent depolarization. $B 2$, Replacement of $\mathrm{Ca}^{2+}$ by $2 \mathrm{mM} \mathrm{Co}^{2+}$ blocked initial low-threshold spike, but not following all-or-none persistent depolarizations with fast spikes. $B 3$, In addition to $\mathrm{Co}^{2+}$, TTX $(1 \mu \mathrm{M})$ abolished persistent depolarizations. Membrane potentials are written on each record. Voltage and current calibrations in $A_{1}$ are applicable to all traces. Time calibrations in $A_{1}, \mathrm{~A}_{2}$, and $B_{1}$ are applicable to $A_{33,5,}$ A 4,6 , and $B 2,3$, respectively.

slow phase clear (Fig. 3B). At threshold, spike firing was delayed because of the slow phase of the depolarizing potential (Fig. $3 A 2$ ). Just above threshold, FS cells fired several spikes with a constant interspike interval. Firing abruptly ceased (Fig. 3A2,3) and sometimes resumed again after a quiescent period within the period of the same depolarizing pulse (Fig. $3 A 2$ ).

Firing patterns of FS cells induced by depolarizing pulses were also reflected in those induced by synaptic excitation. Because resting potentials of FS cells were about $-80 \mathrm{mV}$, a single shock of synaptic stimulation at rest induced only an EPSP or an EPSP with a single spike (Fig. $3 C_{2}$ ). When FS cells were depolarized to -40 to $-30 \mathrm{mV}$ by constant current injection, they responded to synaptic stimulation with a short period of repetitive firing at a relatively constant firing frequency (Fig. $3 C_{1}$ ).

Persistent and low-threshold spike cells (PLTS cells). The other two classes of interneurons were distinguished from FS cells by longer-duration action potentials and larger input resistances (Figs. 2, 5A1), less negative resting potentials, and longer time to peak of afterhyperpolarizations (Table 1). They also had less negative resting potentials and larger input resistances than MS cells (Table 1). These two classes were discriminated by duration of afterhyperpolarizations following spikes. PLTS cells and LA cells had time to peak of afterhyperpolarization following spikes shorter and longer than $30 \mathrm{msec}$, respectively (Table 1, Fig. 4).
PLTS cells were easily distinguished from other classes of cells by two prominent types of spikes in addition to fast spikes, low-threshold spikes, and persistent depolarizing spikes (Fig. 5). Low-threshold spikes could be induced by depolarizing pulses only at potentials more negative than about $-60 \mathrm{mV}$ (Fig. 5A4). In some cases, low-threshold spikes from hyperpolarized potentials were followed by persistent depolarizing spikes (Fig. $5 B_{2}$ ). Low-threshold spikes were also elicited by cessation of hyperpolarizing pulses at depolarized potentials and were continuously followed by persistent depolarizations (Fig. 5A3, $B I$ ). Once activated, persistent depolarizations were noninactivated during depolarized state and were terminated by afterhyperpolarizations following fast spikes (Fig. $5 A 3, B 1,2$ ) or by cessation of depolarizing current pulses (Fig. 6BI).

Both persistent depolarizations and low-threshold spikes in PLTS cells could be evoked by synaptic excitation. At hyperpolarized potentials, all-or-none low-threshold spikes could be induced on evoked EPSPs (Fig. 5A2,B4). If sufficient depolarization resulted from EPSPs and/or by low-threshold spikes on evoked EPSPs, persistent depolarizations could also be induced by synaptic excitation (Fig. $5 B 3$ ).

Electrophysiological characteristics of persistent depolarizations and low-threshold spikes in PLTS cells were investigated by blockers of $\mathrm{Na}^{+}$and $\mathrm{Ca}^{2+}$ channels (Llinás, 1988). Low- 

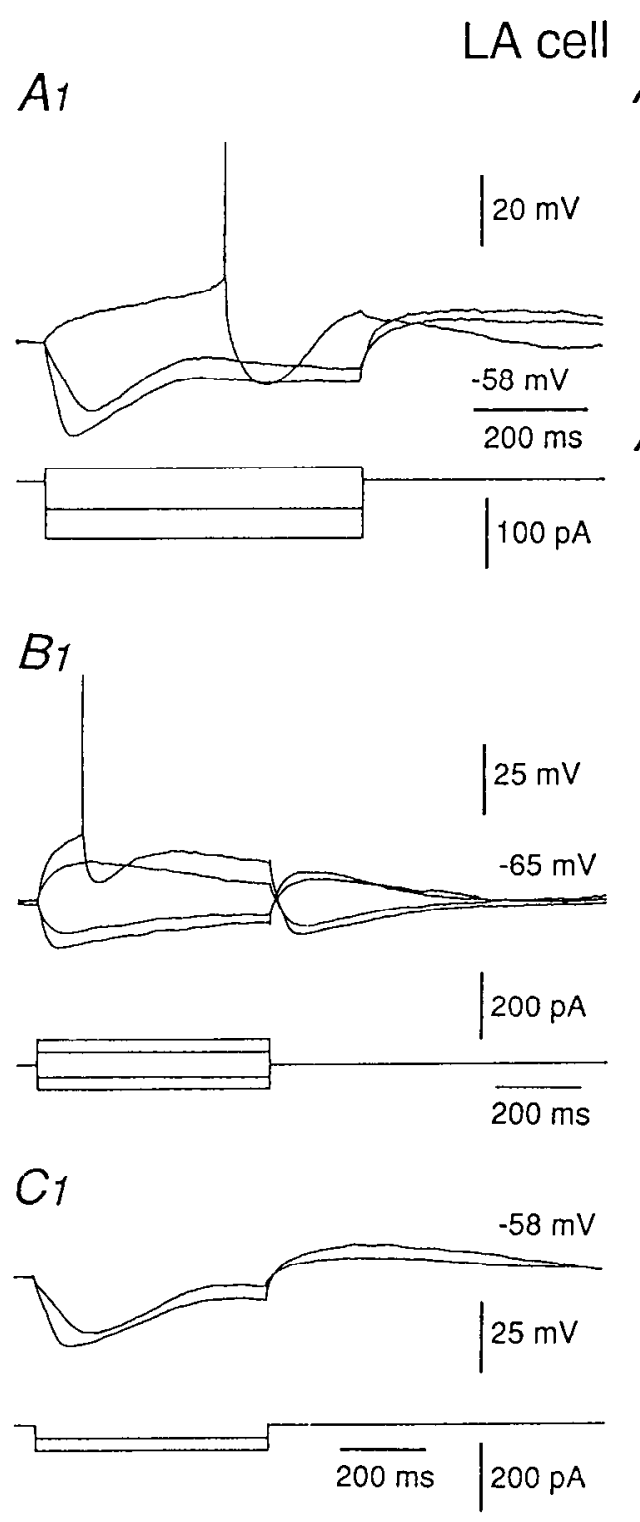

A2
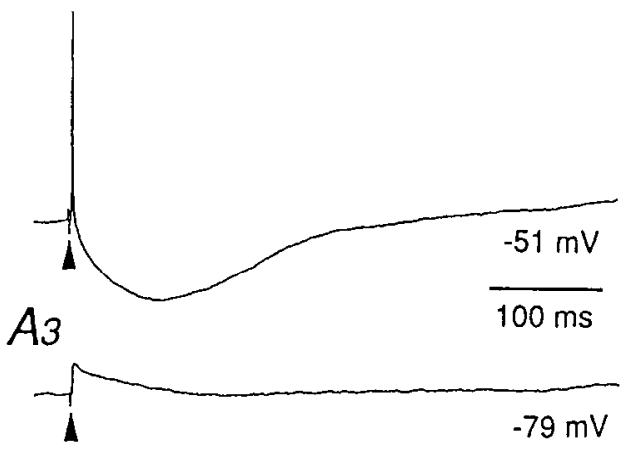

B2 $\mathrm{Co}^{2+}$
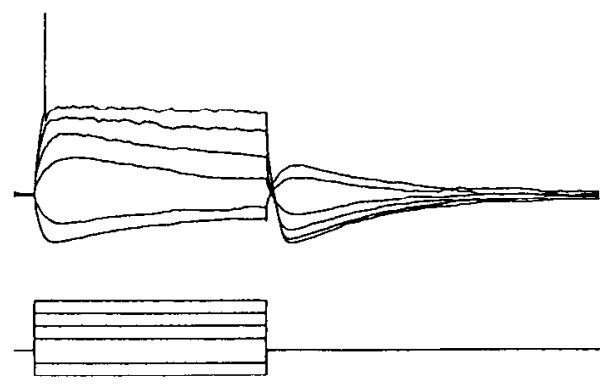

$\mathrm{C2} \mathrm{Cs}^{+}$
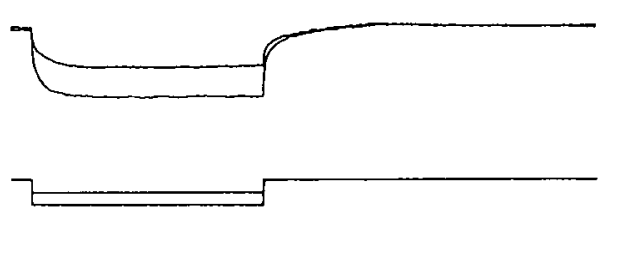

Figure 7. Physiological properties of LA cells. $A_{I}$, Voltage responses and a spike induced by current pulses. Note large afterhyperpolarization following spike and prominent sag during hyperpolarizing pulses. $A_{2}$ and $A 3$. A spike was induced by synaptic excitation (arrowheads) at depolarized potentials, but repetitive discharges could not be induced and a large afterhyperpolarization followed the spike. $B I$ and $B 2$, Large afterhyperpolarizations following a spike $(B t)$ were much reduced by replacement of $\mathrm{Ca}^{2+}$ by $2 \mathrm{mM} \mathrm{Co}^{2+}\left({ }^{2} 2\right)$. $C_{1}$ and $C_{2}$, Prominent sag during hyperpolarizing current pulses $\left(C_{I}\right)$ were suppressed by addition of $2 \mathrm{~mm} \mathrm{Cs}{ }^{+}$ $(C 2)$. Membrane potentials are written on each record. Voltage calibration in $A_{1}$ is applicable to $A_{2}$. Calibrations in $B_{1}$ and $C_{1}$ are applicable to $B_{2}$ and $C_{2}$, respectively. threshold spikes induced by depolarization from hyperpolarized potentials (Fig. $6 A 1,2$ ) could not be blocked by $1 \mu \mathrm{M}$ TTX, a $\mathrm{Na}^{+}$channel blocker $(n=4)$ (Fig. 6A3,4). The remaining lowthreshold spikes in TTX-containing solutions were blocked by replacement of $\mathrm{Ca}^{2+}$ by $2 \mathrm{mM} \mathrm{Co}^{2+}(n=2)$ (Fig. 6A5,6). On the other hand, persistent depolarizations were resistant to replacement of $\mathrm{Ca}^{2+}$ by $\mathrm{Co}^{2+}(n=4)$ (Fig. 6B1,2). However, these persistent depolarizations as well as fast spikes were diminished by addition of TTX to the solution ( $n=3$ ) (Fig. 6B3). These results showed that low-threshold spikes were induced by influx of $\mathrm{Ca}^{2+}$, while persistent depolarizations were due to influx of $\mathrm{Na}^{+}$.

Long-lasting afterhyperpolarization cells ( $L A$ cells). LA cells were separated from FS cells by less negative resting potentials, larger input resistances, larger spike width, and longer-duration afterhyperpolarizations. LA cells had longer times to peak of afterhyperpolarizations following spikes (Table 1). LA cells were also discriminated from MS cells by less negative resting potentials, larger input resistances, and afterhyperpolarizations of longer duration and larger amplitude than MS cells.

LA cells displayed neither persistent depolarization spikes nor low-threshold spikes. Instead, they showed strong time-depen- dent hyperpolarizing rectification, which was observed as a clear return to the starting potential during hyperpolarizing pulses (Fig $7 A 1$ ). Although a time-dependent voltage sag was also observed in PLTS cells during hyperpolarizing pulses (Figs. $\left.5 B_{1}, 6 A 2\right)$, that of LA cells was much more prominent. Synaptic excitation could evoke only single spikes even by strong depolarization (Fig. 7A2), in contrast to FS cells or PLTS cells. This was apparently due to the large long-lasting hyperpolarization following the spike, which suppressed consecutive spike firing.

The ionic basis for long-lasting afterhyperpolarizations and slowly occurring hyperpolarizing rectifications characteristic of LA cells was studied by ionic blockers. Replacing $\mathrm{Ca}^{2+}$ in the perfusate with $2 \mathrm{mM} \mathrm{Co}{ }^{2+}$ made afterhyperpolarizations much smaller without affecting hyperpolarizing rectifications and tail potentials after cessation of current pulses $(n-3)$ (Fig. $7 B 1,2)$. Slowly occurring hyperpolarizing rectifications were blocked by adding $2 \mathrm{~mm}$ cesium in the external solution $(n=4)$ (Fig. $7 C_{1,2}$ ). Depolarizing tail potentials after cessation of hyperpolarizing pulses were also suppressed. These results suggested that longduration afterhyperpolarizations followed by spikes of L.A cells were caused by activation of $\mathrm{Ca}^{2+}$-induced $\mathrm{K}^{+}$channels, while 

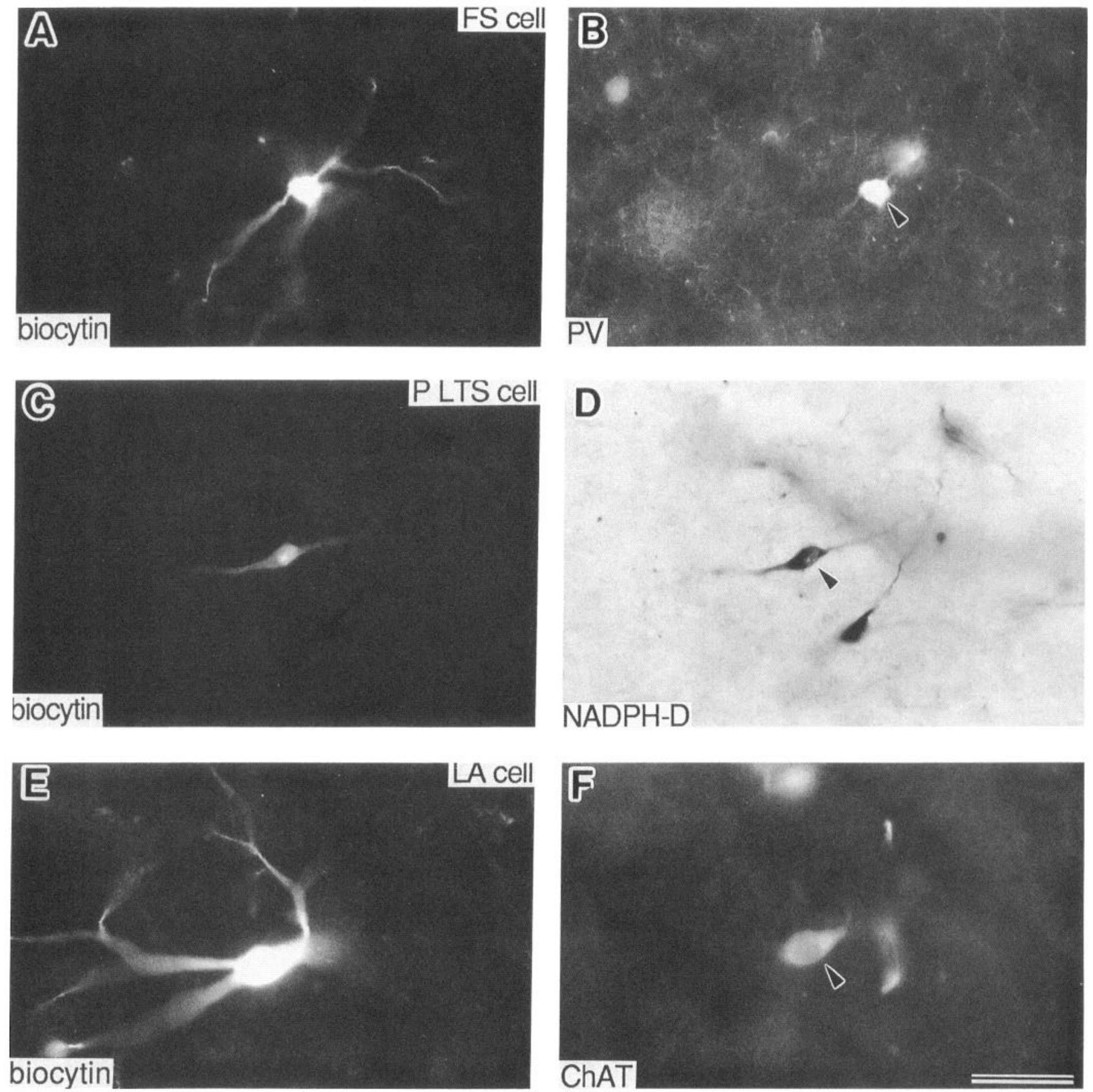

Figure 8. Histochemical identification of FS cells, PLTS cells and LA cells. A, A biocytin-injected FS cell visualized by Texas red-conjugated avidin. $B$, Parvalbumin $(P V)$ immunoreactivity visualized by DTAF-conjugated secondary antibody in the same section as $A$. An identified FS cell was parvalbumin immunoreactive (arrowhead). $C$, A biocytin-injected PLTS cell visualized by Texas red-conjugated avidin. $D$, NADPH diaphorase $(N A D P H-D)$ histochemistry in the same section as $C$. An identified PLTS cell was stained by NADPH diaphorase histochemistry (arrowhead). E, A biocytin-injected LA cell visualized by Texas red-conjugated avidin. $F$, ChAT immunoreactivity visualized by FITC-conjugated secondary antibody in the same section as $E$. An identified LA cell was ChAT immunoreactive (arrowhead). Scale bar, $50 \mu \mathrm{m}$.

slow hyperpolarizing rectifications were induced by activation of $I_{h}$ (Halliwell and Adams, 1982; McCormick and Pape, 1990; Jiang and North, 1991).

Correlation of three chemically identified cell groups with three classes of interneurons in the neostriatum

Neostriatal interneurons are considered to be chemically divided into at least three groups, parvalbumin-immunoreactive cells,
NADPH diaphorase-positive cells, and ChAT-immunoreactive cells. Parvalbumin-positive cells are considered to be more active cells that could induce higher firing rates in the same brain areas (Celio, 1990); in the hippocampus and neocortex a type of cell similar to neostriatal FS cells shows parvalbumin immunoreactivity (Kawaguchi et al., 1987; Kawaguchi and Kubota, 1993). ChAT-positive cells have the largest cell body among neostriatal cells (Bolam et al., 1984b), while parvalbumin- and 

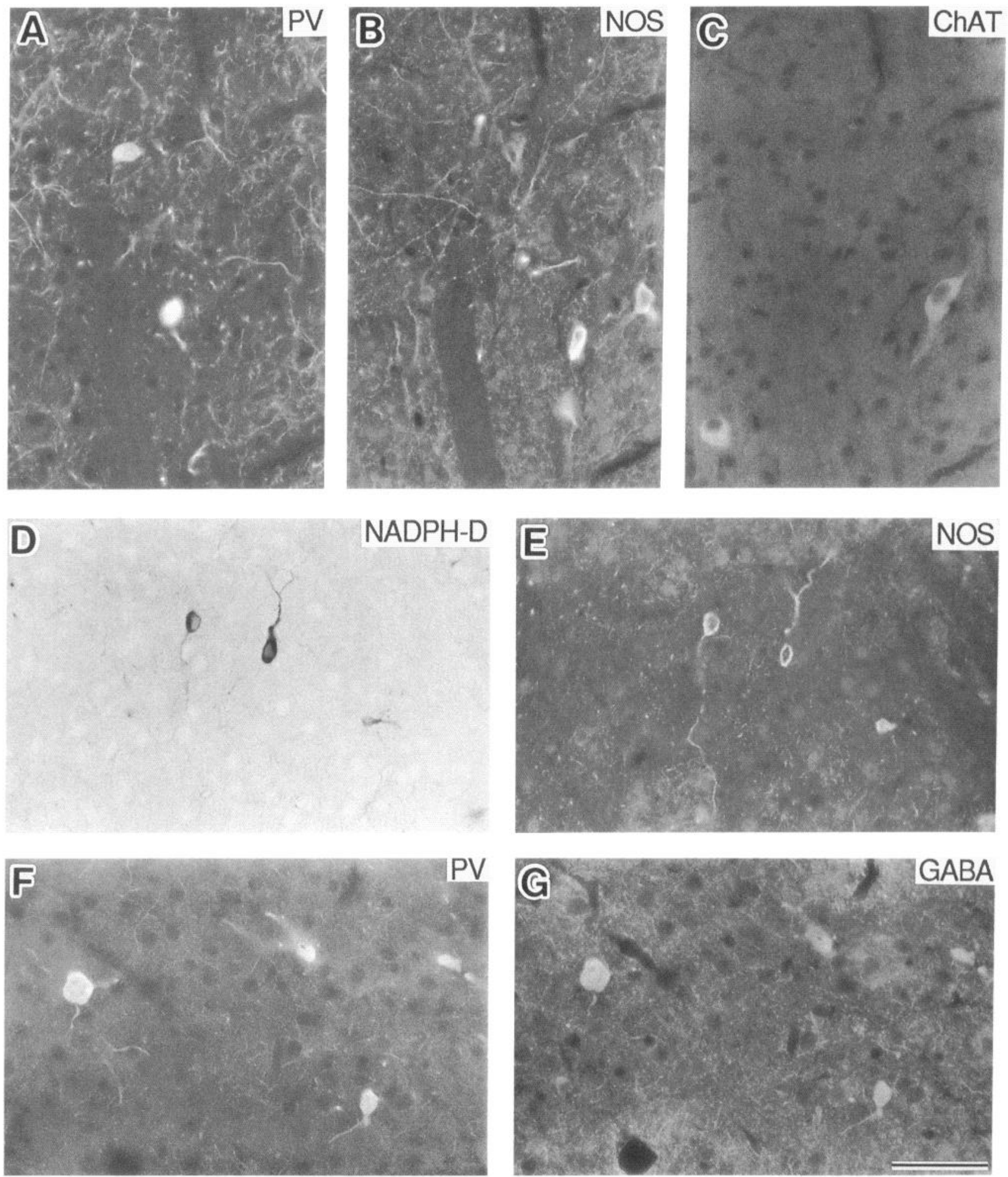

Figure 9. Parvalbumin-, NO synthase (NADPH diaphorase)-, ChAT-positive cells belonged to immunohistochemically separate populations and parvalbumin-immunoreactive cells were also positive for GABA in neostriatum in 20 -d-old rats. $A-C$, Triple photomicrographs from the same microscopic field, showing relationships of neostriatal cells stained immunohistochemically for parvalbumin $(P V)$, NO synthase (NOS), and ChAT. Each type of immunoreactive cells showed no immunoreactivity for the other antigens. $D$ and $E$, Paired photomicrographs from the same microscopic field, showing relationships of cells stained histochemically for NADPH diaphorase (NADPH-D) and immunohistochemically for NO synthase $(N O S)$. NADPH diaphorase-positive cells overlapped with NO synthase-immunoreactive cells. $F$ and $G$, Paired photomicrographs from the same microscopic field, showing relationships of cells stained immunohistochemically for parvalbumin $(P V)$ and GABA. Parvalbumin-immunoreactive cells show GABA immunoreactivity. Scale bar, $50 \mu \mathrm{m}$. 
Figure 10. Reconstruction of an FS cell with local dendritic field (local dend.) and an FS cell with extended dendritic field (extended dend.). Dendrites (Dend.) and axons (Axon) are separately drawn. For comparison of morphological differences among three classes of neostriatal interneurons, Figures 10,12 , and 13 have the same calibration. Axonal origins are indicated by arrows. An FS cell with local dendritic field had smallest dendritic fields. Local axon collaterals were ramified extensively close to the dendritic field. Axon collaterals of an FS cell with extended dendritic field also ramified extensively in similar spatial extent to dendrites.
FS cell (local dend.)
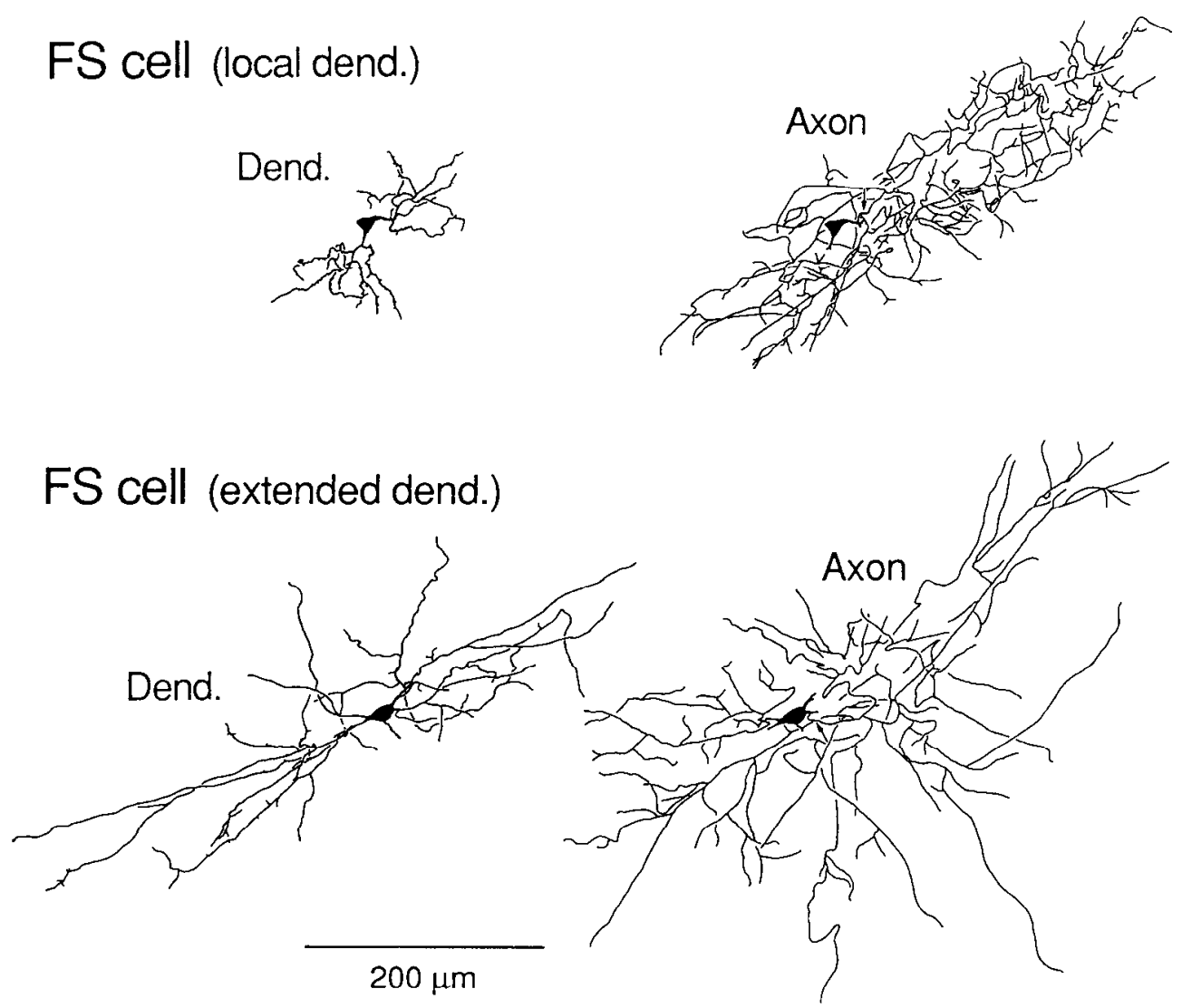

NADPH diaphorase-positive cells have medium-sized perikarya (Vincent et al., 1983; Cowan et al., 1990; Kita et al., 1990). Taken together with the morphological and physiological characteristics of FS cells, PLTS cells, and LA cells described above, these data suggest that FS cells may contain parvalbumin, LA cells may express ChAT, and the remaining PLTS cells may correspond to NADPH diaphorase-positive cells.

To test the hypothesis that each physiologically different class of interneurons corresponds to one of the three separate histochemical classes, histochemical staining was combined with intracellular staining. Physiologically identified neostriatal cells injected with biocytin were visualized by Texas red-conjugated avidin (red fluorescence) (Fig. 8A,C,E). FS cells and LA cells were stained immunohistochemically for parvalbumin and ChAT, respectively. Parvalbumin and ChAT immunoreactivities in recorded cells were visualized by fluorescein-conjugated secondary antibodies (green fluorescence) (Fig. 8B,F). PLTS cells were stained histochemically for NADPH diaphorase. NADPH diaphorase activity could be seen as a blue reaction product in bright field.

Among 11 FS cells tested, 10 cells showed parvalbumin immunoreactivity (Fig. 8A,B). Among nine PLTS cells tested, seven cells showed NADPH diaphorase activity (Fig. $8 C, D$ ). Among 15 LA cells tested, 14 cells showed ChAT immunoreactivity (Fig. $8 E, F$ ). As a control, seven biocytin-loaded MS cells were histochemically stained for parvalbumin, seven for NADPH diaphorase, and five for ChAT. No tested MS cells were stained for any of these substances. Five parvalbumin-immunoreactive FS cells were also further stained histochemically for NADPH diaphorase. All five FS cells tested were negative for NADPH diaphorase histochemistry.
Triple immunofluorescence methods were used to determine whether these three groups belong to separate populations (Fig. $9 A, B, C)$. Because cells stained by NADPH diaphorase histochemistry were also stained by NO synthase immunohistochemistry (Fig. 9D,E), the relationship of parvalbumin-, NO synthase-, and ChAT-immunoreactive cells could be studied by triple immunofluorescent staining. Parvalbumin-positive cells ( $n=244)$, NO synthase-positive cells $(n=144)$, and ChATpositive cells ( $n=139$ ) were always singly stained and were never immunoreactive for the other two antigens (Fig. 9A-C). It was also confirmed by double immunohistochemical staining that all parvalbumin-positive cells were immunoreactive for GABA (Fig. 9F, $G$ ).

These findings showed that three physiological classes of neostriatal interneurons were also unique chemically (FS cells are parvalbumin positive; PLTS cells are NADPH diaphorase positive; LA cells are ChAT positive).

\section{Morphological characteristics of three classes of neostriatal interneurons}

To compare the morphological differences among the three classes of neostriatal interneurons, reconstructions of cells are shown at the same magnification in Figures 10, 12, and 13. Dendrites and axons are separately drawn. Although morphological data, particularly the full extent of dendrites and axons, were limited by slice thickness, each class of interneurons showed a characteristic soma size and arborization of dendrites and axons.

FS cells. The somatic diameters of FS cells sampled in this study ranged from 13 to $28 \mu \mathrm{m}$ (mean $=17 \mu \mathrm{m}$; Table 1 ). Two of 13 cells had diameters larger than $20 \mu \mathrm{m}$. FS cells had round 
or oval somata and three to eight smooth primary dendrites. FS cells seemed to be further divided into two classes depending on the pattern of dendrite extension. Most FS cells (FS cells with local dendritic field, $n=10$ ) had very restricted dendritic fields compared to PLTS cells and LA cells (Fig. 10). Their dendritic fields were $200-300 \mu \mathrm{m}$. In this type of FS cell, the dendrites branched frequently, forming a compact and elaborate field. Local axon collaterals were much more dense than those of PLTS cells and LA cells and were very dense near the dendritic fields. Local axon fields extended to $400-600 \mu \mathrm{m}$ in diameter of field. Some FS cells (FS cells with extended dendritic field, $n=3$ ) had more extended dendrites (Fig. 10). Their dendritic fields were 500-600 $\mu \mathrm{m}$. However, they also had frequently branched dendrites and dense axonal branches close to the dendritic field.

PLTS cells. The somatic diameters of PLTS cells sampled in this study ranged from 12 to $25 \mu \mathrm{m}$ (mean $=19 \mu \mathrm{m}$; Table 1$)$. Four of 11 PLTS cells had diameters larger than $20 \mu \mathrm{m}$. PLTS cells had fusiform or polygonal somata and two to five primary dendrites. The dendrites tended to radiate in straight lines a long way, and were slender and infrequently branched (Figs. 11, 12). The dendrites, to form a field, extended up to $600 \mu \mathrm{m}$ in diameter. Two origins of axon-like processes from the somata and dendrites could be observed in some cases (Figs. 11, 12) (Takagi et al., 1984b). The axons also ran in straight lines, emitting collateral branches and extending to form a field more than $1000 \mu \mathrm{m}$ in diameter (Fig. 12), which was the widest innervation among the three classes of interneurons.

$L A$ cells. The somatic diameters of LA cells sampled in this study ranged from 20 to $40 \mu \mathrm{m}$ (mean $=27 \mu \mathrm{m}$; Table 1$)$. The cells had polygonal or fusiform cell bodies with two to five primary dendrites. Compared to PLTS cells, the dendrites had more branching points and ran in more tortuous trajectories (Fig. 13). The dendrites extended to $600 \mu \mathrm{m}$, similar to those of FS cells with extended dendritic fields and to PLTS cells. The axons changed direction frequently and also took tortuous courses (Fig. 13). The axons extended to 500-700 $\mu \mathrm{m}$, less than PLTS cells.

These findings showed that three classes of neostriatal interneurons with specific physiological and histochemical characteristics had different morphologies as regarding somatic sizes, branching patterns and field sizes of dendrites, and arborization patterns of axons.

\section{Discussion}

This study reveals that neostriatal interneurons can be differentiated into three classes differing in firing modes, chemical content, and territories of dendrites and axons (Fig. 14). FS cells fired very short-duration action potentials with short-duration afterhyperpolarizations at constant spike frequency during depolarizing current steps. FS cells had more negative resting potentials and lower input resistances than the other two classes. At depolarized potentials, FS cells fired repetitive spikes by synaptic excitation. FS cells were identified as parvalbuminimmunoreactive cells, which were also GABA immunoreactive. FS cells had densest innervation within or near the dendritic fields. PLTS cells and LA cells were distinguished from FS cells by longer-duration action potentials, larger input resistances, less negative resting potentials, and longer-lasting afterhyperpolarizations. PLTS cells had smaller time to peak of afterhyperpolarizations than LA cells. PLTS cells fired both $\mathrm{Na}^{+}$-dependent persistent depolarization spikes and $\mathrm{Ca}^{2+}$-dependent

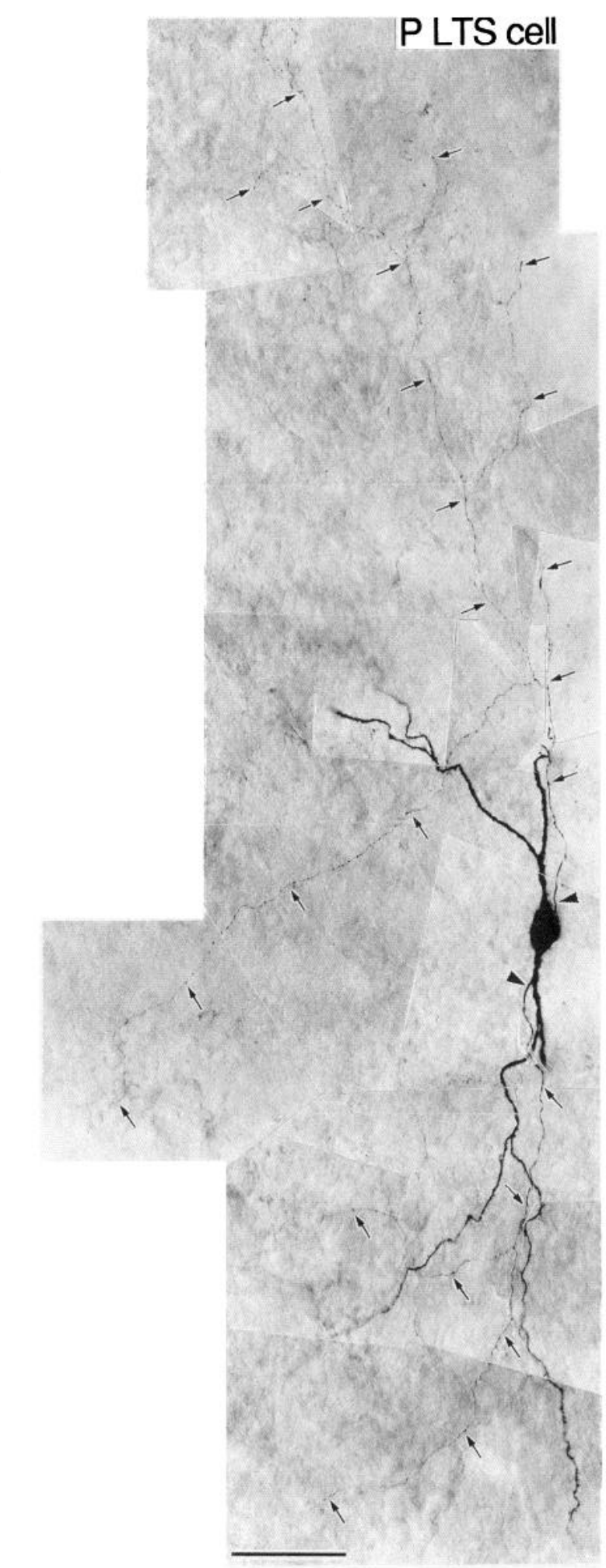

Figure 11. Photomicrograph of a PLTS cell with two axon-like processes. Two origins of axon-like processes indicated by arrowheads and axon-like processes are indicated by arrows. Scale bar, $50 \mu \mathrm{m}$.

low-threshold spikes in addition to fast spikes. Both persistent depolarizations and low-threshold spikes could also be evoked by synaptic activation. PLTS cells were histochemically identified as NADPH diaphorase-positive cells. As NADPH diaphorase-positive cells were also immunoreactive for NO synthase, 


\section{PLTS cell}

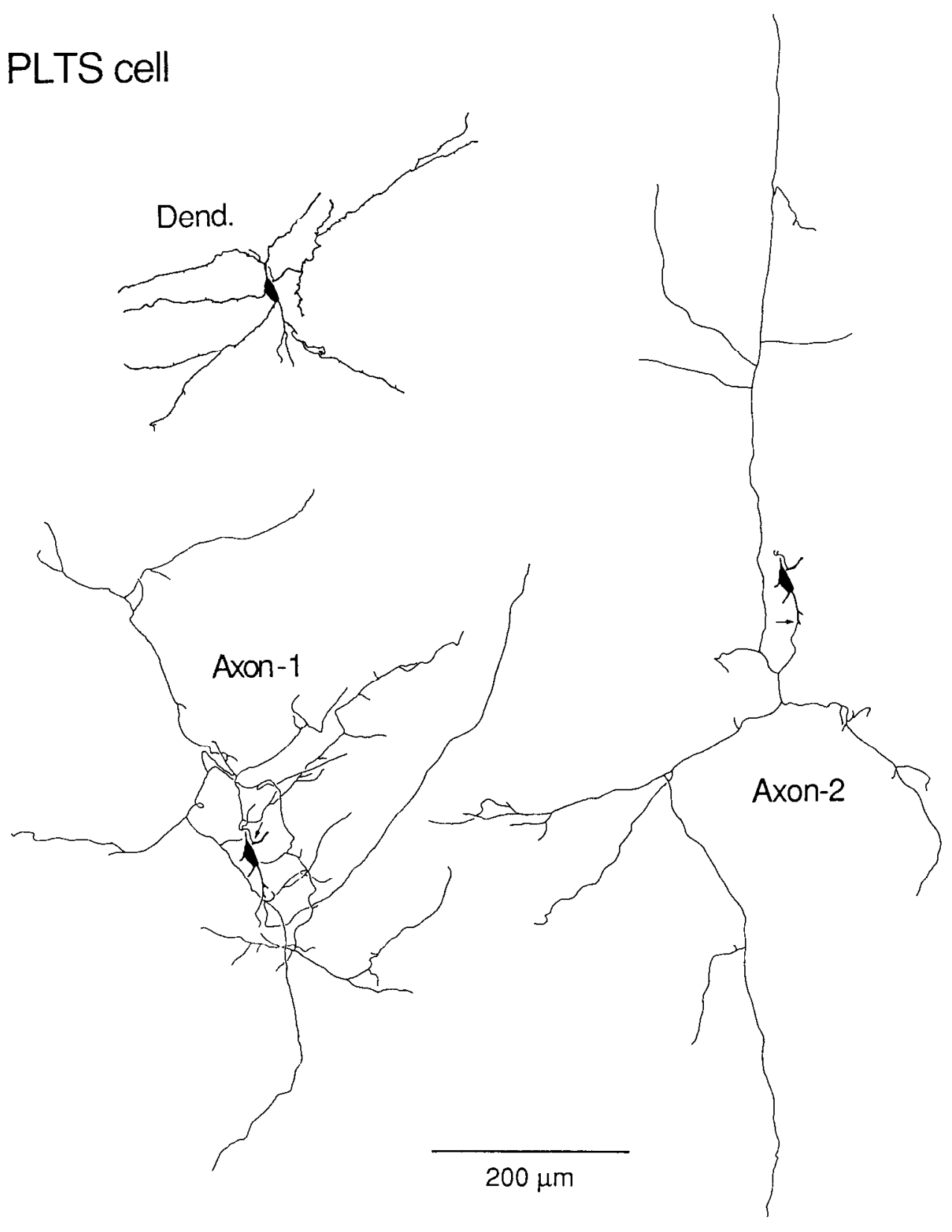

Figure 12. Reconstruction of a PLTS cell with two axon-like processes. Dendrites (Dend.) and two axon-like processes (Axon-1, Axon-2) are separately drawn. Axonal origins are indicated by arrows. Axons of PLTS cells were most widely distributed. Axons tended to run straight.

\section{LA cell}

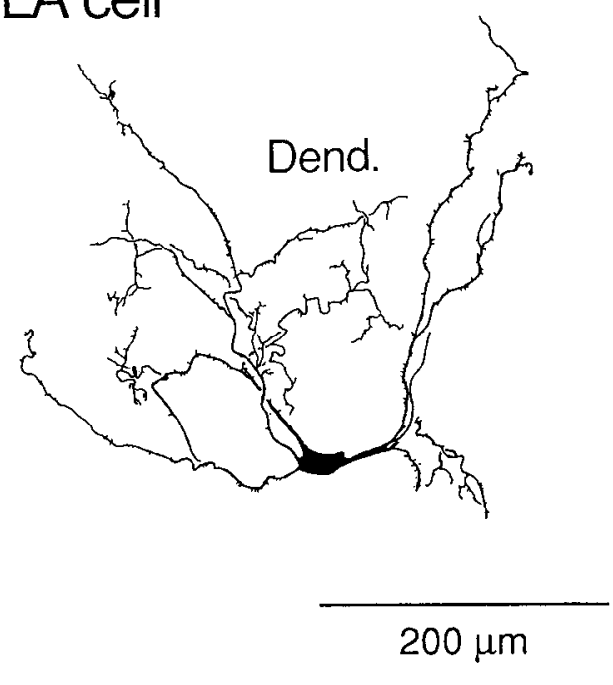

Figure 13. Reconstruction of an LA cell. Dendrites (Dend.) and axons (Axon) are seperately drawn. Axonal origin is indicated by arrow. LA cells were largest cells. Compared to PLTS cells, dendritic and axonal courses were more tortuous than PLTS cells.

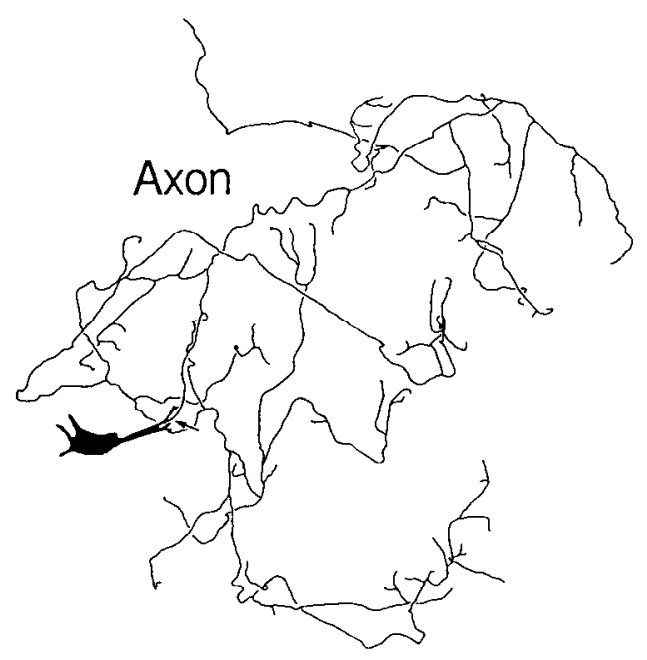



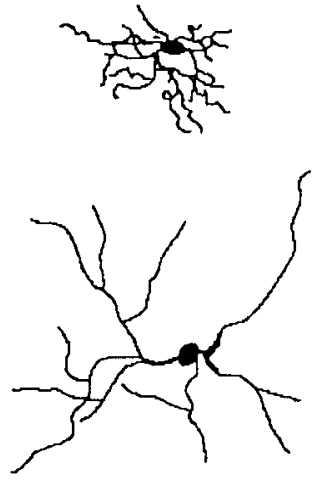

PV (GABA)

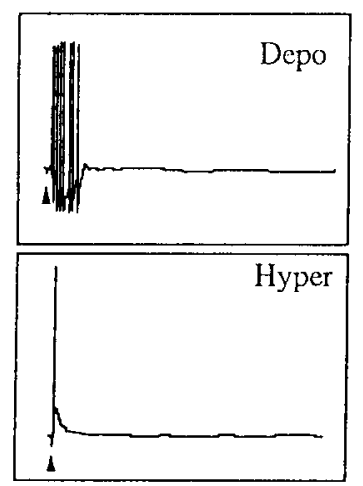

FS cell

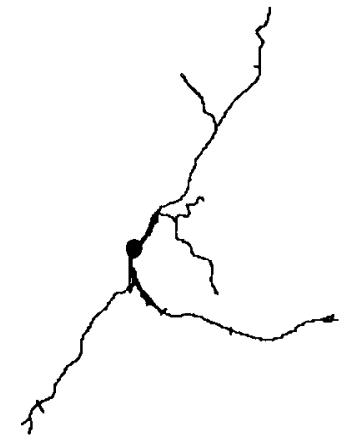

NADPH-D (NO)
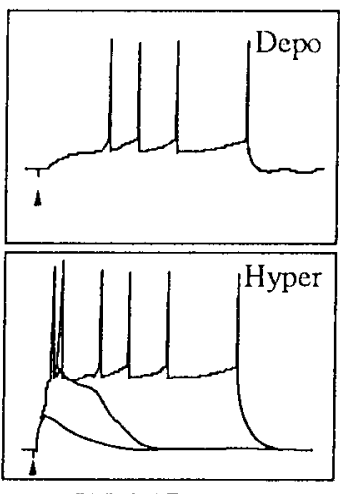

PLTS cell

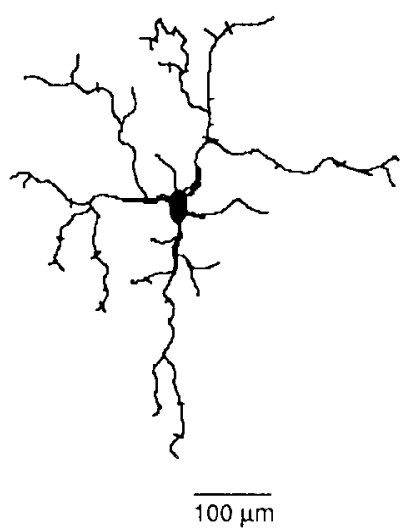

ChAT (Ach)

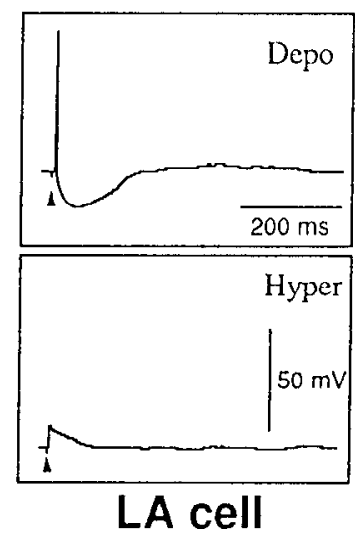

Figure 14. Schematic summary of morphologies, synaptic firing patterns, and neurochemical substances and pulative Iransmitters that the three classes of neostriatal interneurons contain. Dendrites are drawn by solid lines. Axonal drawings are omitted. FS cells were divided into two morphological classes with different dendritic fields. FS cells with local dendritic field (top) and FS cells with extended dendritic field (bottom). Both types of FS cells innervated more densely within or close to the dendritic field than PLTS cells and LA cells. FS cells were parvalbumin $(P V)$-immunoreactive cells that were GABAergic. FS cells showed repetitive firing induced by synaptic activation (arrowhead) at depolarized potentials, which ceased abruptly after a short time. PLIS cells innervated wider areas, in some cells with two axon-like processes with different origins. PLTS cells were NADPH diaphorase ( $N A D P H-D)$-positive cells, which were considered to release NO. PLTS cells showed $\mathrm{Na}^{+}-$ dependent persistent depolarization. $\mathrm{Ca}^{2+}$-dependent low-threshold spikes were also induced by synaptic activation (arrowhead) at hyperpolarized potentials. LA cells were large aspiny cells with diameter larger than $20 \mu \mathrm{m}$. Because LA cells were immunostained for ChAT, they were considered to release $A C h$. LA cells showed long-lasting afterhyperpolarization following spikes, which presumably prevented repetitive firing by synaptic excitation (arrowhead).
PLTS cells were considered to release NO. PLTS cells had the largest axonal fields. Some PLTS cells appeared to have two axonal origins from the somata and/or dendrites. LA cells were large aspiny cells with long-lasting afterhyperpolarizations and strong time-dependent hyperpolarizing rectification. LA cells were identified as ChAT-immunoreactive cells, and are therefore considered to be cholinergic. All LA cells were larger than $20 \mu \mathrm{m}$ in diameter. LA cells had more branched dendrites than PLTS cells. It was also immunohistochemically confirmed that parvalbumin-, NADPH diaphorase-, and ChAT-positive cells belonged to separate neuronal populations.

It is important to note that this study was carried out on tissue from juvenile rats (16-20 d old). It has been shown that membrane potentials and synaptic potentials of neostriatal MS cells mature gradually after birth (Misgeld et al., 1986). Input resistances of MS cells are higher, and fast anomalous rectification of MS cells is less prominent, in rats of postnatal days 7-20. These findings suggest that physiological parameters obtained here in other types may also vary somewhat from adult rats.

To sample a greater number of aspiny interneurons, larger cells were preferentially recorded. This might lead to a lack of recording from additional populations of smaller interneurons. Although parvalbumin-immunoreactive cells and NADPH diaphorase-positive cells contain populations with small somatic diameters similar to those of MS cells (Vincent et al., 1983; Kita et al., 1990), these may have physiological characteristics similar to those with larger diameters. However, there may be aspiny cells with diameters similar to or smaller than those of MS cells and with physiological properties qualitatively different from those of the three types of aspiny cells described here. For example, neostriatal cells immunoreactive for cholecystokinin (Takagi et al., 1984a), vasoactive intestinal polypeptide (Theriault and Landis, 1987), or calretinin (Bennett and Bolam, 1993) are aspiny in type and have diameters similar to MS cells. Therefore, in addition to the three types of interneurons mentioned above, other physiological subclasses of aspiny cells may be found.

\section{FS cells}

From electrophysiological and parvalbumin-immunohistochemical data in this report, FS cells are considered to be GABAergic interneurons with phasic repetitive firing induced by synaptic activation at depolarized potentials. MS cells in the striatum receive disynaptic IPSPs from the cortex by a feedforward pathway via striatal intrinsic neurons (Wilson et al., 1989; Pennartz and Kitai, 1991) and these IPSPs are blocked by bicuculline, a $\mathrm{GABA}_{\mathrm{A}}$ receptor antagonist (Pennartz and $\mathrm{Ki}$ tai, 1991). The cortical afferents end directly on parvalbuminimmunoreactive cells in asymmetric synapses, while the parvalbumin-immunoreactive terminals have symmetrical synapses on somata and dendrites of the neostriatal cells, probably including MS cells (Kita et al., 1990; Lapper et al., 1992). Therefore, FS cells may be excited by cortical afferents, mediate feedforward $\mathrm{GABA}_{\mathrm{A}}$ inhibition on neostriatal projection neurons, and thus regulate excitability or threshold of the output cells. As parvalbumin-immunoreactive fibers make synapses also on 
spine-free dendrites (Kita et al., 1990), FS cells may also mediate inhibition on interneurons.

FS cells had very dense axon collaterals near their somata. The neostriatum has patch and matrix compartments that differ in histochemical characteristics and in the origin of their afferents (Graybiel, 1990; Gerfen, 1992). Because axonal branches were dense near the somata and not particularly widespread, each FS cell may inhibit neostriatal cells belonging to only the compartment in which it lies, patch or matrix. The other intrastriatal inhibitory interactions are lateral and recurrent connections among MS cells that are GABAergic (Park et al., 1980; Wilson and Groves, 1980; Somogyi et al., 1981). This inhibition is only activated when projection MS cells fire, which corresponds to feedback inhibition. It is very important to clarify different functional roles between feedforward inhibition by FS cells and feedback inhibition by MS cells.

Because FS cells could fire repetitively by synaptic activation at depolarized potentials, they should be able to inhibit neostriatal cells strongly. Neostriatal MS cells exhibit characteristic shifts of membrane potential between depolarized and hyperpolarized states in vivo (Wilson and Groves, 1981; Wilson, 1990). By their phasic repetitive firing, FS cells may suppress depolarization in the dendrites where prolonged depolarization may be caused by afferent inputs (Wilson, 1990) and change prolonged depolarizations to a long-lasting hyperpolarized state in MS cells, or may reduce spike firing in a prolonged episode of depolarization.

\section{PLTS cells}

PLTS cells exhibited unique firing properties due to $\mathrm{Ca}^{2+}$-dependent low-threshold spikes and $\mathrm{Na}^{+}$-dependent persistent depolarized spikes, in addition to $\mathrm{Na}^{+}$-dependent fast spikes. PLTS cells were histochemically active for NADPH diaphorase. Because NADPH diaphorase is identical to NO synthase (Dawson ct al., 1991), PLTS cells are considered to release NO within the neostriatum. These cells are also considered to contain neuropeptide Y (NPY) and somatostatin (Vincent et al., 1983; Dawson et al., 1991). However, a "classical" neurotransmitter in this group of cells has not been identified yet. There is one report that NPY-immunoreactive cells are also stained for GAD, the synthetic enzyme for GABA (Vuillet et al., 1990). If PLTS cells are also GABAergic, neostriatal GABAergic interneurons would be functionally divided into two classes by differences in firing patterns, innervation areas and co-released substances. As NPYimmunoreactive cells directly receive cortical inputs (Vuillet et al., 1989a) and NPY-immunoreactive terminals, like parvalbumin-immunoreactive ones, make synapses on perikarya and dendrites of neostriatal cells including MS cells (Vuillet et al., 1989 b), PLTS cells are considered to regulate MS cells in a feedforward manner from the cortex, like FS cells. Thus, cortical cells may affect MS cells through two types of interneurons of medium size within the neostriatum.

Some PLTS cells had two origins of axon-like processes, which innervated different areas. In the neostriatum, a medium aspiny cell with two axons forming synapses has been reported by Golgi-impregnated material (Takagi et al., 1984b), which also suggests that some neostriatal interneurons can have two axons. In the visual cortex of the cat, nonpyramidal cells with two axon-like processes are also described (Mayer, 1982). In the neostriatum and the neocortex, a subpopulation of interneurons may have multiple axons.

NO may be released when PLTS cells are activated. NO is a messenger molecule that is suggested to be involved in the regulations of blood flow, synaptic efficacy, and glutamate toxicity (Bredt and Snyder, 1992). Fxcitation in the corticostriatal pathway is mediated by excitatory amino acids released from cortical afferents onto both AMPA/kainate and NMDA receptor subtypes (Cherubini et al., 1988). Recently it has been shown that NO inhibits NMDA receptor function in cultured neostriatal cells (Manzoni et al., 1992). During prolonged depolarizations PLTS cells may produce NO, and modulate excitatory NMDA receptor-mediated transmission in MS cells over a wide area.

\section{$L A$ cells}

Physiological properties of these large aspiny cells were qualitatively similar to those investigated previously (Jiang and North, 1991; Kawaguchi, 1992). In this article, these cells were identified as the cells immunoreactive for ChAT. Large afterhyperpolarizations following spikcs and slowly occurring hypcrpolarizing rectification were revealed here to be due to $\mathrm{Ca}^{2+}$ influx by spikes and $I_{h}$ current, respectively. LA cells fire single spikes due to large afterhyperpolarizations that suppress repetitive firing. The morphological and electrophysiological data suggest that tonically active large aspiny cells described in vivo (Kimura et al., 1984; Wilson et al., 1990) are identical to LA cells, and may thus be cholinergic.

ChAT-immunoreactive cells receive thalamic inputs from the parafascicular nucleus of the thalamus, at least on their proximal dendrites (Lapper and Bolam, 1992). Compared with FS cells and PLTS cells, activities of LA cells may be influenced more by thalamic afferents. However, afferent fibers from the parafascicular nucleus almost exclusively innervate the matrix compartment (Herkenham and Pert, 1981; Sadikot et al., 1992) and distal dendrites of LA cells extend also into the patch compartment (Penny et al., 1988; Kawaguchi, 1992). LA cells innervate preferentially the matrix compartment (Kawaguchi, 1992). These data suggest that cholinergic LA cells may integrate input from both the thalamic axons at the matrix and the unidentified fibers in the patch, and affect projection cells in the matrix.

ChAT-immunoreactive terminals end on dendritic shafts and perikarya of MS cells in symmetrical synapses (lzzo and Bolam, 1988). It has been proposed that ACh stabilizes the state of MS cells, whether it be a depolarized or a hyperpolarized state (Akins et al., 1990). Firing of LA cells may thus stabilize membrane potential of nearby MS cells either at excitable states in which MS cells can fire or at a hyperpolarized state in which MS cells cannot fire. This suggests that membrane potentials and synaptic potentials in MS cells may be modulated differentially by three classes of interneurons, GABAergic FS cells, PLTS cells producing NO, and cholinergic LA cells.

\section{References}

Akins P, Surmeier J, Kitai ST (1990) Muscarinic modulation of a transient $K$ conductance in rat neostriatal neurons. Nature 344:240242.

Bennett BD, Bolam JP (1993) Characterization of calretinin-immunoreactive structures in the striatum of the rat. Brain Res 609:137148.

Bolam JP, Ingham CA, Smith AD (1984a) The section-Golgi-impregnation procedure. 3 . Combination of Golgi-impregnation with enzyme histochemistry and electron microscopy to characterize acetylcholinesterase-containing neurons in the rat neostriatum. Neuroscience 12:687-709.

Bolam JP, Wainer BH, Smith AD (1984b) Characterization of cholinergic neurons in the rat striatum. A combination of choline ace- 
tyltransferase immunocytochemistry, Golgi-impregnation, and electron microscopy. Neuroscience 121:711-718.

Bredt DS, Snyder SH (1992) Nitric oxide, a novel neuronal messenger. Neuron 8:3-11.

Calabresi P, Mercuri NB, Bernardi G (1990) Synaptic and intrinsic control of membrane excitability of neostriatal neurons. II. An in vitro analysis. J Neurophysiol 63:663-675.

Celio MR (1990) Calbindin D-28k and parvalbumin in the rat nervous system. Neuroscience 35:375-475.

Chang HT, Wilson CJ, Kitai ST (1982) A Golgi study of rat neostriatal neurons: light microscopic analysis. J Comp Neurol 208:107-126.

Cherubini E, Herrling PL, Lanfumey L, Stanzione P (1988) Excitatory amino acids in synaptic excitation of rat striatal neurones in vitro. $\mathbf{J}$ Physiol (Lond) 400:677-690.

Cowan RL, Wilson CJ, Emson PC, Heizmann CW (1990) Parvalbumin-containing GABAergic interneurons in the rat neostriatum. $J$ Comp Neurol 302:197-205.

Dawson TM, Brcdt DS, Fotuhi M, Hwang PM, Snyder SH (1991) Nitric oxide synthase and neuronal NADPH diaphorase are identical in brain and peripheral tissues. Proc Natl Acad Sci USA 88:77977801.

DiFiglia M, Pasik P, Pasik T (1976) A Golgi study of neuronal types in the neostriatum of monkeys. Brain Res 114:245-256.

Dimova R, Vuillet J, Seite R (1980) Study of the rat neostriatum using a combined Golgi-electron microscope technique and serial sections. Neuroscience 5:1581-1596.

Gerfen CR (1988) Synaptic organization of the striatum. J Electr Microsc Tech 10:265-281.

Gerfen CR (1992) The neostriatal mosaic: multiple levels of compartmental organization. Trends Neurosci 15:133-138.

Graybiel AM (1990) Neurotransmitters and neuromodulators in the basal ganglia. Trends Neurosei 13:244-254.

Halliwell JV, Adams PR (1982) Voltage clamp analysis of muscarinic excitation in hippocampal neurons. Brain Res 250:71-92.

Herkenham M, Pert CB (1981) Mosaic distribution of opiate receptors, parafascicular projections and acetylcholinesterase in the rat striatum. Nature 291:415-418.

Horikawa H, Armstrong WE (1988) A versatile means of intracellular labeling: injection of biocytin and its detection with avidin conjugates. J Neurosci Meth 25:1-11.

Izzo PN, Bolam JP (1988) Cholinergic synaptic input to different parts of spiny striatonigral neurons in the rat. J Comp Neurol 269:219234

Jiang Z-G, North RA (1991) Membrane properties and synaptic responses of rat neostriatal neurons in vitro. J Physiol (Lond) 443:533553.

Kawaguchi Y (1992) Large aspiny cells in the matrix of the rat neostriatum in vitro: physiological identification, relation to the compartments and excitatory postsynaptic currents. J Neurophysiol 67: $1669-1682$.

Kawaguchi Y, Kubota Y (1993) Correlation of physiological subgroupings of nonpyramidal cells with parvalbumin- and calbindin ${ }_{\mathrm{D} 28 \mathrm{k}}-\mathrm{im}$ munoreactive neurons in layer $\mathrm{V}$ of rat frontal cortex. J Neurophysiol 70:387-396.

Kawaguchi Y, Katsumaru H, Kosaka T, Heizmann CW, Hama K (1987) Fast spiking cells in rat hippocampus (CAl regions) contain the calcium-binding protein parvalbumin. Brain Res 416:369-374.

Kawaguchi Y, Wilson CJ, Emson PC (1989) Intracellular recording of identified neostriatal patch and matrix spiny cells in a slice preparation preserving cortical inputs. J Neurophysiol 62:1052-1068.

Kimura M, Raijkowski J, Evarts E (1984) Tonically discharging putamen neurons exhibit set dependent responses. Proc Natl Acad Sci USA 81:4998-5001.

Kita H, Kosaka T, Heizmann CW (1990) Parvalbumin-immunoreactive neurons in the rat neostriatum: a light and electron microscopic study. Brain Res 536:1-15.

Kita T, Kita H, Kitai ST (1984) Passive electrical membrane properties of rat neostriatal neurons in in vitro slice preparation. Brain Res 300: 129-139.

Lapper SR, Bolam JP (1992) Input from the frontal cortex and the parafascicular nucleus to cholinergic interneurons in the dorsal striatum of the rat. Neuroscience 51:533-545.

Lapper SR, Smith Y, Sadikot AF, Parent A, Bolam JP (1992) Cortical input to parvalbumin-immunoreactive neurones in the putamen of the squirrel monkey. Brain Res 580:215-224.

Llinás RR (1988) The intrinsic electrophysiological properties of mammalian neurons: insights into central nervous system function. Science 242:1654-1664.

Manzoni O, Prezeau L, Marin P, Deshager S, Bockaert J, Fagni L (1992) Nitric oxide-induced blockade of NMDA receptors. Neuron 8:653662.

Mayer G (1982) Short-axon neurons with two axon-like processes in the visual cortex of the cal. A Golgi study. Brain Res 232:455-459.

McCormick DA, Pape H-C (1990) Properties of a hyperpolarizationactivated cation current and its role in rhythmic oscillation in thalamic relay neurones. J Physiol (Lond) 431:291-318.

Misgeld U, Dodt HU, Frotscher M (1986) Late development of intrinsic excitation in the rat neostriatum: an in vivo study. Dev Brain Res 27:59-67.

Park MR, Lighthall JW, Kitai ST (1980) Recurrent inhibition in the rat neostriatum. Brain Res 194:359-369.

Pennartz CMA, Kitai ST (1991) Hippocampal inputs to identified neurons in an in vitro slice preparation of the rat nucleus accumbens: evidence for feed-forward inhibition. J Neurosci 11:2838-2847.

Penny GR, Wilson CJ, Kitai ST (1988) Relationship of the axonal and dendritic geometry of spiny projection neurons to the compartmental organization of the neostriatum. J Comp Neurol 269:275289.

Phelps PE, Houser CR, Vaughn JE (1985) Immunocytochemical localization of choline acetyltransferase within the rat neostriatum: a correlated light and electron microscopic study of cholinergic neurons and synapses. J Comp Neurol 238:286-307.

Sadikot AF, Parent A, Smith Y, Bolam JP (1992) Efferent connections of the centromedian and parafascicular nuclei in the squirrel monkey. A light and electron microscopic study of the thalamostriatal projection in relation to striatal heterogeneity. J Comp Neurol 320:228242.

Somogyi P, Bolam JP, Smith AD (1981) Monosynaptic cortical input and local axon collaterals of identified striatonigral neurons. A light and electron microscopic study using the Golgi-peroxidase transportdegeneration procedure. J Comp Neurol 195:567-584.

Takagi H, Mizuta H, Matsuda T, Inagaki S, Tateishi K, Hamaoka T (1984a) The occurrence of cholecystokinin-like immunoreactive neurons in the rat neostriatum: light and electron microscopic analysis. Brain Res 309:346-349.

Takagi H, Somogyi P, Smith AD (1984b) Aspiny neurons and their local axons in the neostriatum of the rat: a correlated light and electron microscopic study of Golgi-impregnated material. J Neurocytol 13: 239-265.

Theriault E, Landis DMD (1987) Morphology of striatal neurons containing VIP-like immunoreactivity. J Comp Neurol 256:1-13.

Vincent SR, Johansson O, Hökfelt T, Skirboll L, Elde RP, Terenius L, Kimmel J, Goldstein M (1983) NADPH-diaphorase: a selective histochemical marker for striatal neurons containing both somatostatin- and avian pancreatic polypeptide (APP)-like immunoreactivities. J Comp Neurol 217:252-263.

Vuillet J, Kerkerian-Le Goff L, Kachidian P, Bosler O, Nieoullon A (1989a) Ultrastructural correlates of functional relationships between nigral dopaminergic or cortical afferent fibers and neuropeptide $\mathrm{Y}$ containing neurons in the rat striatum. Neurosci Lett 100:99-104.

Vuillet J, Kerkerian L, Kachidian P, Salin P, Nieoullon A (1989b) Ultrastructural features of NPY-containing neurons in the rat striatum. Brain Res 477:241-251.

Vuillet J, Kerkerian-Le Goff L, Kachidian P, Dusticier G, Bosler O, Nieoullon A (1990) Striatal NPY-containing neurons receive GABAergic afferents and may also contain GABA: an electron microscopic study in the rat. Eur J Neurosci 2:672-681.

Wilson CJ (1990) The basal ganglia. In: The synaptic organization of the brain (Shepherd GM, ed), pp 279-316. New York: Oxford UP.

Wilson CJ, Groves PM (1980) Fine structure and synaptic connections of the common spiny neuron of the rat neostriatum: a study employing intracellular injection of horseradish peroxidase. J Comp Neurol 194: 599-615.

Wilson CJ, Groves PM (1981) Spontaneous firing patterns of identified spiny neurons in the rat neostriatum. Brain Res 220:67-80.

Wilson CJ, Kita H, Kawaguchi Y (1989) GABAergic interneurons, rather than spiny cell axon collaterals, are responsible for the IPSP responses to afferent stimulation in neostriatal spiny neurons. Soc Neurosci Abstr 15:907.

Wilson CJ, Chang HT, Kitai ST (1990) Firing patterns and synaptic potentials of identified giant aspiny interneurons in the rat neostriatum. J Neurosci 10:508-519. 